Article

\title{
The Impact of the Madden-Julian Oscillation on Cyclone Amphan (2020) and Southwest Monsoon Onset
}

\author{
Heather L. Roman-Stork *(D) and Bulusu Subrahmanyam \\ School of the Earth, Ocean and Environment, University of South Carolina, Columbia, SC 29208, USA; \\ sbulusu@geol.sc.edu \\ * Correspondence: hromanstork@seoe.sc.edu
}

Received: 2 August 2020; Accepted: 14 September 2020; Published: 16 September 2020

\begin{abstract}
Cyclone Amphan was an exceptionally strong tropical cyclone in the Bay of Bengal that achieved a minimum central pressure of $907 \mathrm{mb}$ during its active period in May 2020. In this study, we analyzed the oceanic and surface atmospheric conditions leading up to cyclogenesis, the impact of this storm on the Bay of Bengal, and how the processes that led to cyclogenesis, such as the Madden-Julian Oscillation (MJO) and Amphan itself, in turn impacted southwest monsoon preconditioning and onset. To accomplish this, we took a multiparameter approach using a combination of near real time satellite observations, ocean model forecasts, and reanalysis to better understand the processes involved. We found that the arrival of a second downwelling Kelvin wave in the equatorial Bay of Bengal, coupled with elevated upper ocean heat content and the positioning of the convective phase of the $\mathrm{MJO}$, helped to create the conditions necessary for cyclogenesis, where the northward-propagating branch of the $\mathrm{MJO}$ acted as a trigger for cyclogenesis. This same MJO event, in conjunction with Amphan, heavily contributed atmospheric moisture to the southeastern Arabian Sea and established low-level westerlies that allowed for the southwest monsoon to climatologically onset on June 1 .
\end{abstract}

Keywords: tropical cyclones; Bay of Bengal; southwest monsoon; Madden-Julian Oscillation; Kelvin waves

\section{Introduction}

Tropical cyclones are among the most powerful atmospheric systems on the planet, playing a critical role in heat and energy transport, impacting mixed layer dynamics and aquatic ecosystems, and having devastating effects on coastal populations [1-4]. Globally, there are annually over 80 tropical cyclones on average [5], with an average of 5 to 6 occurring in the Bay of Bengal and accounting for roughly $7 \%$ of global tropical cyclones annually [2]. While not the most active basin, the Bay of Bengal still averages 2 to 3 severe cyclonic storms annually, and these can have devastating impacts on the populations of India, Bangladesh, and Myanmar in particular [2]. Seasonally, most cyclones in the Bay of Bengal occur in May and November, just prior to the southwest (May) and northeast (November) monsoons [2,5], with the large vertical wind shear during monsoon seasons suppressing cyclone activity [1].

From May 15 to 21, 2020, Cyclone Amphan formed in the southern Bay of Bengal before propagating northward and devastating parts of India and Bangladesh. Amphan occurred at a unique time, following an anomalously strong positive Indian Ocean Dipole (IOD) in 2019 and occurring during a neutral El Niño-Southern Oscillation (ENSO) phase [6,7]. Statistically, the most severe cyclones in the Bay of Bengal occur during positive IOD and La Niña years [8], and this was certainly the case with Cyclone Amphan, which reached a minimum central pressure of $907 \mathrm{mb}$ after rapid intensification 
and was categorized as a Very Severe Cyclonic Storm (equivalent of category 5 on the Saffir-Simpson scale). The timing of this storm was also unique because it occurred just prior to a southwest monsoon onset on June 1 and simultaneously with an equatorially downwelling Kelvin wave in the Bay of Bengal and the Madden-Julian Oscillation (MJO).

The MJO is an eastward-propagating system with a phase speed of roughly $5 \mathrm{~m} / \mathrm{s}$ that is characterized by alternating bands of suppressed and enhanced convection over the equator [9-13]. While it operates on a 30-90-day timescale, it is closely related to the 30-60-day boreal summer intraseasonal oscillation (BSISO), which is a northward-propagating phenomenon in the northern Indian Ocean that has been known to heavily impact monsoon precipitation and onset [13-16]. The MJO is the dominant form of intraseasonal variability in the tropics [12,13] and is widely known to impact cyclogenesis on a global scale $[5,17,18]$. Planetary waves in general, particularly atmospheric waves, have been clearly shown to create conditions that are favorable for cyclogenesis, and they have therefore been the subject of intense study [4,5,14,17-19]. A composite analysis of global tropical cyclones from 1974 to 2002 comparing cyclogenesis with planetary wave and MJO propagation found that the spring peak in cyclones in the northern Indian Ocean coincided with MJO, equatorial Rossby wave, and Kelvin wave activity [5]. This study further found that these waves and the MJO enhance the tendency for genesis by increasing low-level vorticity and enhancing convective vertical motion, as well as that cyclogenesis tended to occur within the convectively active portion of waves and the MJO [5]. A case study of Typhoon Rammasun (2002) and Typhoon Chataan (2002) in the North Pacific used satellite observations from the Tropical Rainfall Measurement Mission (TRMM) to find that the passage of the MJO and associated convectively-coupled Kelvin waves established equatorial westerlies and created potential vorticity anomalies that were favorable for cyclogenesis as a consequence of the atmospheric diabatic heating created by the MJO and Kelvin waves [17]. Another study of the MJO and atmospheric Kelvin waves [19] used the National Aeronautics and Space Administration's (NASA's) Modern-Era Retrospective Analysis for Research and Applications (MERRA) reanalysis to show, through composite analysis, that wind anomalies favorable for cyclogenesis were more persistent when a Kelvin wave and the MJO were both present. This study showed that the Kelvin wave established the wind anomalies but that the MJO established the enhanced duration of the winds. A composite study of BSISO phase and cyclogenesis in the Bay of Bengal [18] using best track and reanalysis data found that there was a higher genesis potential in May and October-November due to a weak vertical shear, but it was also found that there was an even higher genesis potential associated with the passage of the BSISO due to enhanced relative humidity and absolute vorticity. Overall, it has been found that the convection, low-level moisture, vorticity (relative, potential, and absolute), and shear associated with these waves can help provide a triggering mechanism for cyclogenesis and can help precondition the atmosphere and ocean for cyclone formation [5,14,17-19]. In contrast, oceanic downwelling planetary waves in the Bay of Bengal have mainly been found to impact mixed layer processes, such as the coupling of sea surface temperatures (SSTs) and sea level anomalies (SLAs) due to the convergence of freshwater and shoaling of the mixed layer [4].

In addition to impacting tropical cyclogenesis, the MJO and BSISO have also been shown to impact southwest monsoon onset [20-24]. The southwest monsoon began on June 1 over the southwestern state of Kerala following the genesis of a monsoon onset vortex over the southeastern Arabian Sea and the Arabian Sea Mini Warm Pool in May [20,25-30]. Low salinity waters are transported by the North Equatorial Current (NEC) and East India Coastal Current (EICC) from the Bay of Bengal into the southeastern Arabian Sea in winter, which creates a fresh pool that allows for the formation of a barrier layer that prevents entrainment cooling. This, in turn, allows for a buildup of heat and the formation of the Arabian Sea Mini Warm Pool in spring, with SSTs exceeding $31^{\circ} \mathrm{C}$. Given their impacts on coastal Kelvin wave propagation and therefore freshwater transport into the southeastern Arabian Sea, this whole process is heavily influenced by both the ENSO and the IOD [26,31]. In addition to the Arabian Sea Mini Warm Pool, onset requires the convergence of moisture and heat in the southeastern Arabian Sea, along with low-level kinetic energy and the establishment of low-level 
westerlies $[20,23,24]$. The MJO and BSISO both impact monsoon onset through the establishment of low-level westerlies and the transport of moisture into the southeastern Arabian Sea, where the phase of each intraseasonal oscillation (ISO) can heavily impact the strength and timing of onset $[20,21,23,24]$.

In this study, a multiparameter analysis using satellite observations from blended altimetry, NASA's Soil Moisture Active Passive (SMAP) mission, the joint NASA and Japan Aerospace Exploration Agency (JAXA) Global Precipitation Measurement (GPM) mission, the National Oceanic and Atmospheric Administration's (NOAA's) Optimum Interpolation Sea Surface Temperature (OISST), and Remote Sensing Systems' (RSS') Cross-Calibrated Multi-Platform (CCMP) blended surface winds was performed in conjunction with model output from ECMWF's Nucleus for the European Modeling of the Ocean (NEMO) and 5th generation ECMWF Reanalysis (ERA5) in order to understand (i) how the $\mathrm{MJO}$ and oceanic processes contributed to cyclogenesis, (ii) how the Bay of Bengal responded to the storm, and (iii) how the storm and the MJO contributed to southwest monsoon onset. This case study revealed that a combination of a downwelling equatorial Kelvin wave, an MJO event, and mixed layer conditions in the Bay of Bengal helped to create the oceanic conditions necessary for cyclogenesis in the southern Bay of Bengal and allowed for the near-meridional propagation and rapid intensification of the storm system. This same MJO event, in conjunction with Amphan, helped to precondition the southeastern Arabian Sea for southwest monsoon onset on June 1. This paper is organized as follows: Section 2 presents the materials and methods used in this study, Section 3 presents the results of our research, Section 4 discusses the major findings, and Section 5 concludes this study.

\section{Materials and Methods}

\subsection{Data}

\subsubsection{Satellite Data}

Precipitation rate data were taken from the joint NASA/JAXA GPM mission. The GPM mission was originally designed as the follow-on mission to NASA's TRMM, which is no longer operational. The daily merged microwave/infrared near real time (NRT) GPM product was used in this study and is available from NASA's Earthdata database on a $0.1^{\circ}$ horizontal grid from March 2014 to present [32].

Blended surface wind data from RSS' CCMP version 2.0 (CCMPv2.0) NRT product were used [33]. CCMP uses a combination of scatterometer winds, buoy data, and ERA-Interim reanalysis to create a 6-hourly blended wind product that is available from 1987 to present, although it is most reliable beginning in the 1990s. CCMP data are available on a $0.25^{\circ}$ horizontal grid and are made into a daily mean. Due to its horizontal grid spacing, it may be difficult for the CCMP to fully resolve the maximum wind speed in the inner core of a tropical cyclone, but it should adequately capture the relative size and mean winds within the rest of the storm to the extent possible in a $0.25^{\circ}$ gridded product.

Sea level anomalies (SLAs) and surface geostrophic currents were obtained from the Copernicus Marine and Environment Monitoring Service (CMEMS; marine.copernicus.eu) in NRT and are available from 1993 to present as a daily product on a $0.25^{\circ}$ horizontal grid [34,35]. SLAs and currents are from a daily merged altimetry product that combines data from all available altimeters and interpolates it to daily. SLAs are in reference to a 20-year mean from 1993 to 2012.

Sea surface salinity (SSS) data from NASA's SMAP version 3 were obtained from NASA's Physical Oceanography Distributed Active Archive Center (PO.DAAC) [36]. Here, we used the Jet Propulsion Lab (JPL)-processed data using the combined active passive algorithm. While SMAP has an 8-day return period, it has near global coverage every 3 days that is interpolated to a daily product, which was used in this study. Daily SMAP data are available from 2015 to present on a $0.25^{\circ}$ horizontal grid.

SST data were taken from NOAA's OISST [37]. OISST uses observations from the Advanced Very High Resolution Radiometer (AVHRR) on NOAA satellites. Daily data were obtained from NOAA's Physical Sciences Laboratory (PSL). This daily product is available from 1981 to present in daily temporal resolution on a $0.25^{\circ}$ horizontal grid. 
Ocean color (chlorophyll) data were taken from the NOAA MSL12 Ocean Color NRT multi-sensor DINEOF gap-filled analysis [38]. This novel ocean color product uses the DINEOF method to gap-fill ocean color data from the Visible Infrared Imaging Radiometer Suite (VIIRS) onboard the Suomi National Polar-Orbiting Partnership (SNPP) and NOAA-20 satellites to eliminate the cloud contamination and other forms of contamination, such as sun glint, that usually plague ocean color observations. Using a gap-filled product such as this is highly beneficial in particular when studying events that necessarily accompany a great deal of cloud cover, such as a tropical cyclone. This NRT product is available from 2018 to present in a daily format.

Cyclone track data were obtained from the Joint Typhoon Warning Center (JTWC) via NOAA's National Environmental Satellite, Data and Information Service (NESDIS) [39].

\subsubsection{Model Forecasts}

Ocean model forecasts from ECMWF's NEMO version 3.1 were obtained from CMEMS [40]. NEMO is perhaps most well-known for being the ocean model component in the ECMWF forecast, but it has been used with increasing frequency for studies in the Indian Ocean and the Bay of Bengal [41,42]. While reasonably reliable in the Bay, NEMO has been shown to have a $1^{\circ} \mathrm{C}$ cold SST bias in the northern Bay of Bengal and a warm SST bias in the southeastern tropical Indian Ocean [41]. As the main problems with NEMO's SST simulations in the northern Indian Ocean appear with colder SSTs [41], particularly during the winter months, this should not have had a substantial impact on our results, particularly when considered in concert with satellite observations. NEMO forecasts are available with $1 / 12^{\circ}$ horizontal resolution, making it eddy-resolving, and they come with 50 stratified depths. Data were taken from CMEMS as 10-day forecasts with daily temporal resolution and are available from 2016 to present.

Surface flux data (instantaneous moisture flux, surface latent heat flux, and surface sensible heat flux) were taken from the ECMWF ERA5 reanalysis as hourly data [43]. ERA5 data are available on a $0.25^{\circ}$ horizontal grid from 1979 to present and were obtained on one level from the Copernicus Climate Change Service (C3S). ERA5 is the successor to ERA-40 and ERA-Interim, which have been widely used in studies of the tropical Indian Ocean [44]. Unless otherwise specified, ERA5 flux data were averaged into a daily format to be consistent with NEMO model output and satellite observations.

\subsection{Methods}

\subsubsection{Ocean Heat Content}

The upper ocean heat content $(\mathrm{OHC})$ in the top $30 \mathrm{~m}$ of the water column $(0-30 \mathrm{~m})$ was calculated as in [26] from NEMOv3.1 daily model forecasts using the equation:

$$
\text { OHC }=\int_{30 \mathrm{~m}}^{0 \mathrm{~m}} \rho C_{p} T d z
$$

where the $O H C$ is calculated for the upper $30 \mathrm{~m}, \rho$ is the seawater density $\left(\mathrm{kg} / \mathrm{m}^{3}\right)$ calculated using the equation of state, $C_{p}$ is the specific heat capacity of seawater $\left(3930 \mathrm{~J} \mathrm{~kg}^{-1}{ }^{\circ} \mathrm{C}^{-1}\right)$ [45], and $T$ is the mean temperature $\left({ }^{\circ} \mathrm{C}\right)$ over $d z$, the depth thickness $(\mathrm{m})$.

\subsubsection{Mixed Layer Depth, Isothermal Layer Depth, and Mixed Layer Depth}

Mixed layer depth (MLD), isothermal layer depth (ILD), and barrier layer thickness (BLT) were calculated from NEMOv3.1 daily model forecasts as in [26] and following the methods of [46]. A $0.03 \mathrm{~kg} / \mathrm{m}^{3}$ density criteria for defining MLD, which was found to be appropriate for tropical regions with high diurnal variability such as the northern Indian Ocean, was used [46]. Both MLD and ILD were calculated with a temperature difference, $d T$, of $0.2^{\circ} \mathrm{C}$. 


\subsubsection{Bandpass Filtering}

To isolate the MJO signal, time-latitude fields were bandpass filtered using a 30-90-day range, as in $[12,13]$. A 4th order Butterworth bandpass filter was used, and the fields were double filtered to eliminate edge effects. This technique has been reliably used by previous studies in the Bay of Bengal for identifying and isolated intraseasonal oscillations $[12,13,15,42,47,48]$. The average seasonal cycle from 2017 to 2019 of all fields was removed prior to filtering in order to isolate the MJO signal and to create consistent anomalies across products.

\section{Results}

\subsection{Cyclone Overview}

\subsubsection{Cyclone Track}

The track of Cyclone Amphan showed that the storm was generated around $8^{\circ} \mathrm{N}$ and $86^{\circ} \mathrm{E}$ in the southern Bay (Figure 1), allowing for equatorial processes, such as equatorially trapped planetary waves and the $\mathrm{MJO}$, to have potential influences on cyclogenesis. After propagating northwest on May 15, the system moved along a nearly meridional track in the Bay of Bengal between $86^{\circ} \mathrm{E}$ and $89^{\circ} \mathrm{E}$ from May 16 through May 20, at which point it made landfall in West Bengal. The storm continued to move over land in eastern India and Bangladesh through May 21 before dissipating.

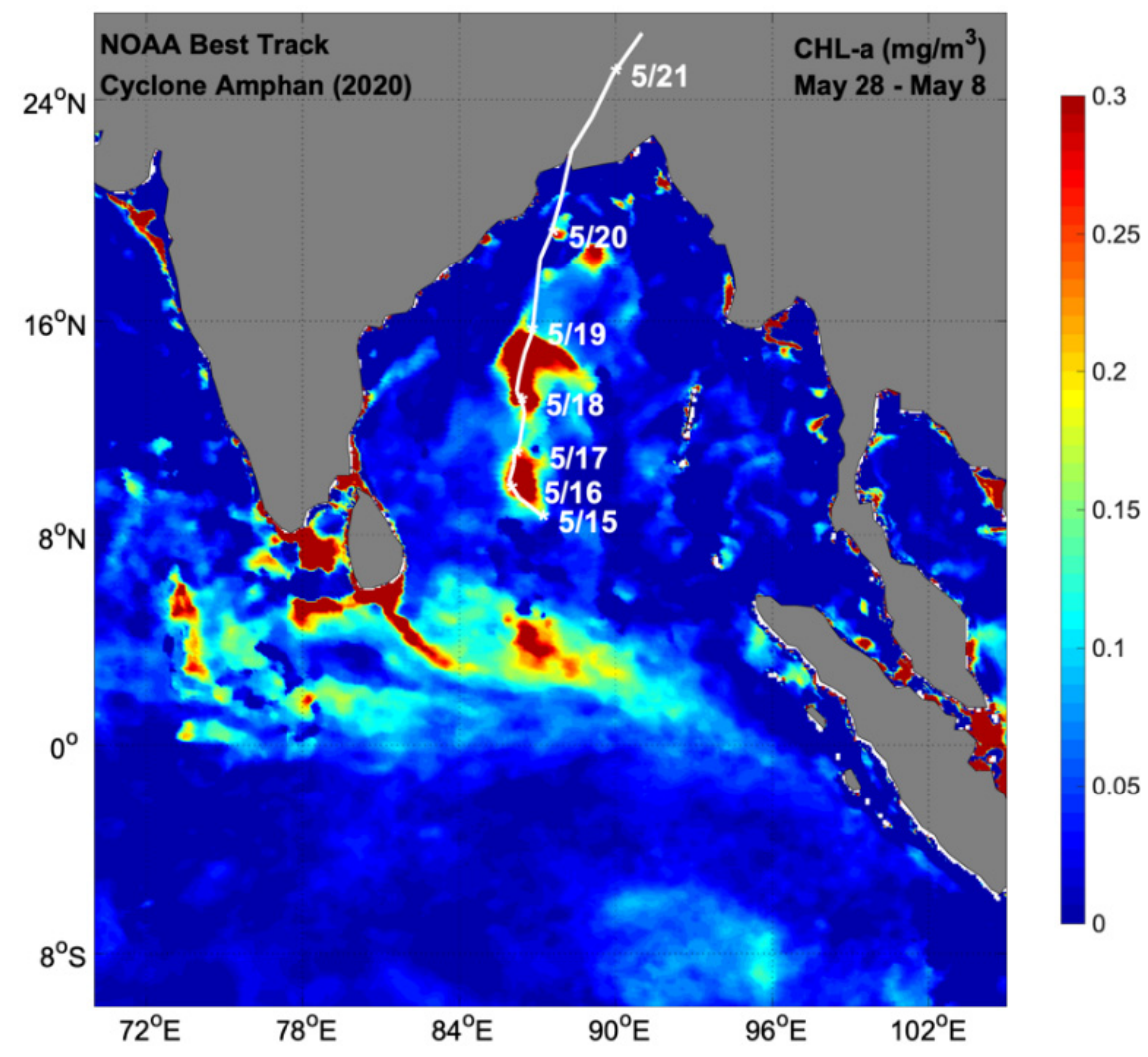

Figure 1. National Oceanic and Atmospheric Administration (NOAA) Coastwatch gap-filled ocean color chlorophyll-a (CHL-a; shaded; mg/m³ ) for the difference between May 28, 2020 and May 8, 2020 in the Bay of Bengal overlaid with NOAA Satellite Services Division (SSD) best track data from the Joint Typhoon Warning Center (JTWC) for Cyclone Amphan (2020).

The storm track in Figure 1 is superimposed over NOAA NRT gap-filled ocean color data, demonstrating the impact Amphan had on the Bay. The Bay of Bengal is normally a highly anoxic basin [1], with the only productivity being concentrated around coastlines and the large river deltas. 
By comparing the difference in ocean color one week after and one week before the passage of Amphan, however, we can see large blooms in the central Bay that follow the storm track, particularly in the central Bay, where the productivity is comparable to that of coastal regions. There is an additional bloom seen around $5^{\circ} \mathrm{N}$ and $85^{\circ} \mathrm{E}$ possibly related to the passage of the MJO or upwelling associated with the smaller systems that later developed into Amphan. The gap-filled ocean color data nicely demonstrate the extent to which Amphan impacted different regions of the Bay of Bengal. In the following sections, we explore how the storm developed and influenced surface and mixed layer processes in the Bay.

\subsubsection{Multiparameter Analysis}

A multiparameter analysis of Cyclone Amphan before (Figure 2), during (Figure 3), and after (Figure 4) the passage of the storm through the Bay of Bengal showed the response of the Bay to the storm. Prior to cyclogenesis (Figure 2), there was scattered precipitation in the equatorial region near Sri Lanka and in the Andaman Sea. In SLA, two large anticyclonic eddies could be observed in the EICC region of the Bay, although most of the Bay is dominated by low SLAs and cyclonic eddies (Figure 2B). SSTs at this time were in excess of $32{ }^{\circ} \mathrm{C}$ (Figure 2C), with corresponding OHC values near $8 \times 10^{9} \mathrm{~J} / \mathrm{m}^{2}$ in the north/central Bay, particularly west of $90^{\circ} \mathrm{E}$ (Figure 2E). SSS showed reasonably low values in the majority of the Bay, with higher salinity along the east coast of India and below $5^{\circ} \mathrm{N}$. Surface winds were also reasonably calm in most of the Bay, with only near-equatorial processes producing winds in excess of $10 \mathrm{~m} / \mathrm{s}$ (Figure 2I). In the southern Bay, however, winds were stronger than in other regions of the Bay, exceeding $5 \mathrm{~m} / \mathrm{s}$ and being predominantly northeasterly and easterly, with winds beginning to converge around the genesis region. Near-equatorial winds across the northern Indian Ocean remained strong and were predominantly northwesterly over the Arabian Sea. Surface fluxes (Figure 2J-L) showed that the majority out outward fluxes were confined to the southern/central Bay $\left(10^{\circ} \mathrm{N}, 82-95^{\circ} \mathrm{E}\right)$, with downward fluxes dominating the rest of the Bay. It is notable that this is the region of cyclogenesis and is also where the highest magnitude surface winds were observed in the Bay.

The most striking feature of the pre-cyclone Bay, however, was the clear arrival of a downwelling Kelvin wave, specifically the first downwelling Kelvin wave [46] at the Sumatra coast, which was evident in SLA, BLT MLD, and ILD data (Figure 2B,F-H). This downwelling Kelvin wave drastically increased MLD and ILD to below a $40 \mathrm{~m}$ depth in the equatorial region and increased BLT up to $10^{\circ} \mathrm{N}$ in areas of the Bay.

On 19 May, at the peak of storm intensity, precipitation was heavily concentrated at the center of the storm in the northwestern Bay and skirting the edge of the coast (Figure 3A). Further precipitation could be observed from $5-10^{\circ} \mathrm{S}$ near the Sumatra coast. The anticyclonic eddies in Figure $2 \mathrm{~B}$ can be seen to have decreased in radius (Figure 3B), particularly the northernmost eddy that was directly beneath the storm. A clear upwelling pattern could be seen in the SST, SSS, and OHC data, with SSTs below 27 ${ }^{\circ} \mathrm{C}$, an SSS exceeding $34 \mathrm{psu}$, and an $\mathrm{OHC}$ below $7 \times 10^{9} \mathrm{~J} / \mathrm{m}^{2}$ along the storm track (Figure 3C-E). Directly below the storm, however, SSTs remained above $31^{\circ} \mathrm{C}$ and the $\mathrm{OHC}$ remained fairly high along the coast, which continued to sustain the storm. Cyclone-strength winds were confined to the storm center, although extremely high winds could be seen near the equator $\left(0-5^{\circ} \mathrm{N}\right.$; Figure $\left.3 \mathrm{I}\right)$. Moisture and latent heat fluxes appeared to follow a similar pattern to surface wind (Figure 3I,J,L), with high amplitude fluxes in regions of high surface wind. While sensible heat fluxes followed a similar pattern (Figure 3K), there were pronounced positive fluxes in the western Bay, with negative fluxes in the eastern Bay and in areas of high surface wind. The arrival of the first downwelling Kelvin wave was pronounced (Figure 3B,F-H), with extremely high SLAs and BLT exceeding $40 \mathrm{~m}$ off the Sumatra coast. In addition to the deepening of the mixed, barrier, and isothermal layers along the equator, there was significant deepening observed along the storm track, with the ILD in the majority of the Bay exceeding $40 \mathrm{~m}$. 

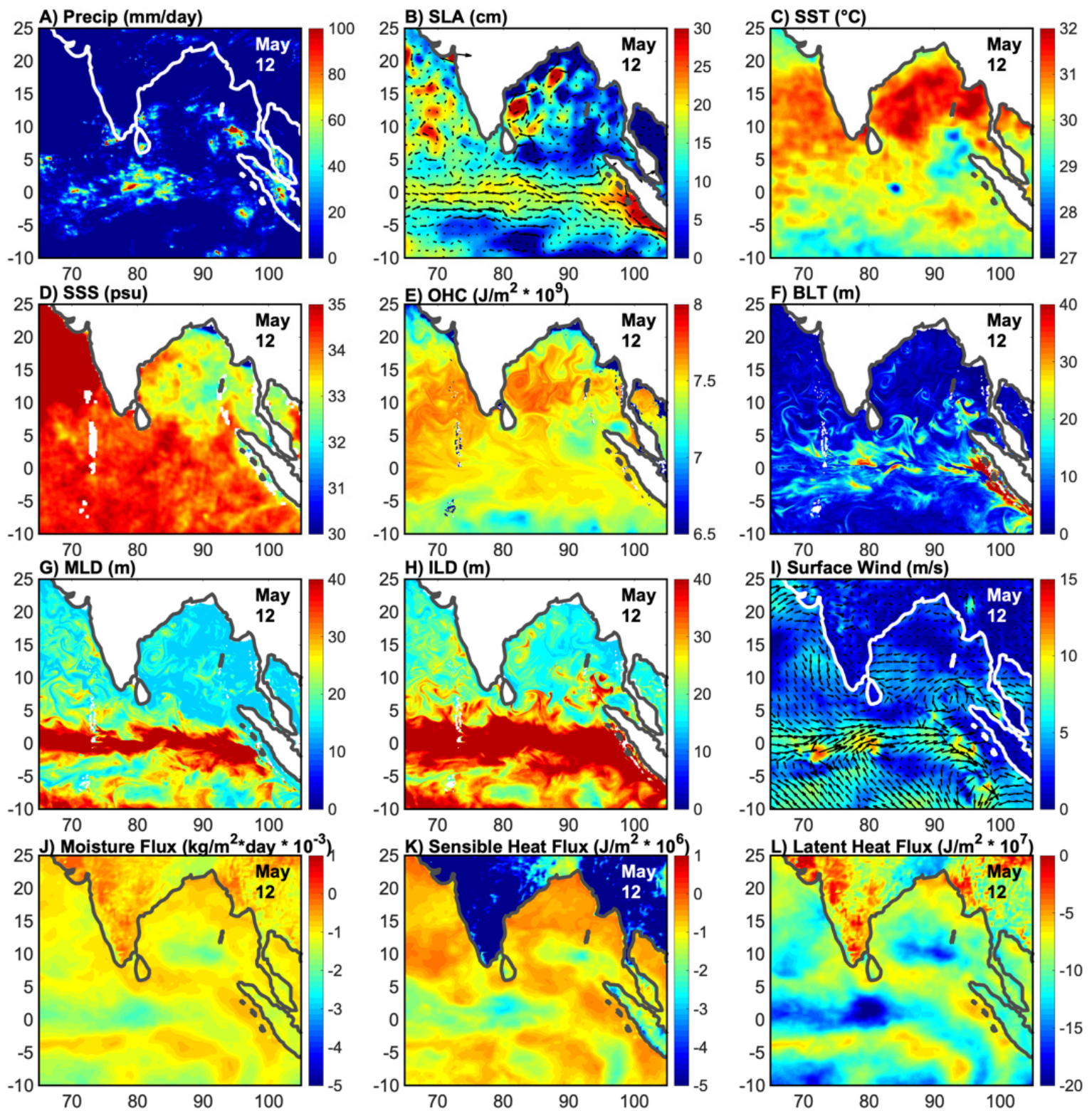

Figure 2. Multiparameter analysis of the Bay of Bengal on May 12, 2020 prior to cyclogenesis in (A) Global Precipitation Measurement (GPM) precipitation rate (mm/day); (B) Copernicus Marine and Environment Monitoring Service (CMEMS) sea level anomalies (SLAs) (cm) overlaid with geostrophic currents (cm/s); (C) Nucleus for the European Modeling of the Ocean (NEMO) sea surface temperature (SST) data $\left({ }^{\circ} \mathrm{C}\right)$; (D) NEMO sea surface salinity (SSS) data (psu); (E) 0-30 m ocean heat content (OHC; $\mathrm{J} / \mathrm{m}^{2 *} 10^{9}$ ) calculated from NEMO; (F) barrier layer thickness (BLT; $\mathrm{m}$ ) calculated from NEMO; (G) mixed layer depth (MLD; m) calculated from NEMO; (H) isothermal layer depth (ILD; m) calculated from NEMO; (I) Cross-Calibrated Multi-Platform version 2 (CCMPv2) surface wind magnitude ( $\mathrm{m} / \mathrm{s}$; shaded) and vectors; (J) ERA5 instantaneous moisture flux $\left(\mathrm{kg} / \mathrm{m}^{2 *} \mathrm{day}^{*} 10^{-3}\right)$; (K) ERA5 surface sensible heat flux $\left(\mathrm{J} / \mathrm{m}^{2} * 10^{6}\right)$; and $(\mathbf{L})$ ERA5 surface latent heat flux $\left(\mathrm{J} / \mathrm{m}^{2} * 10^{7}\right)$. 

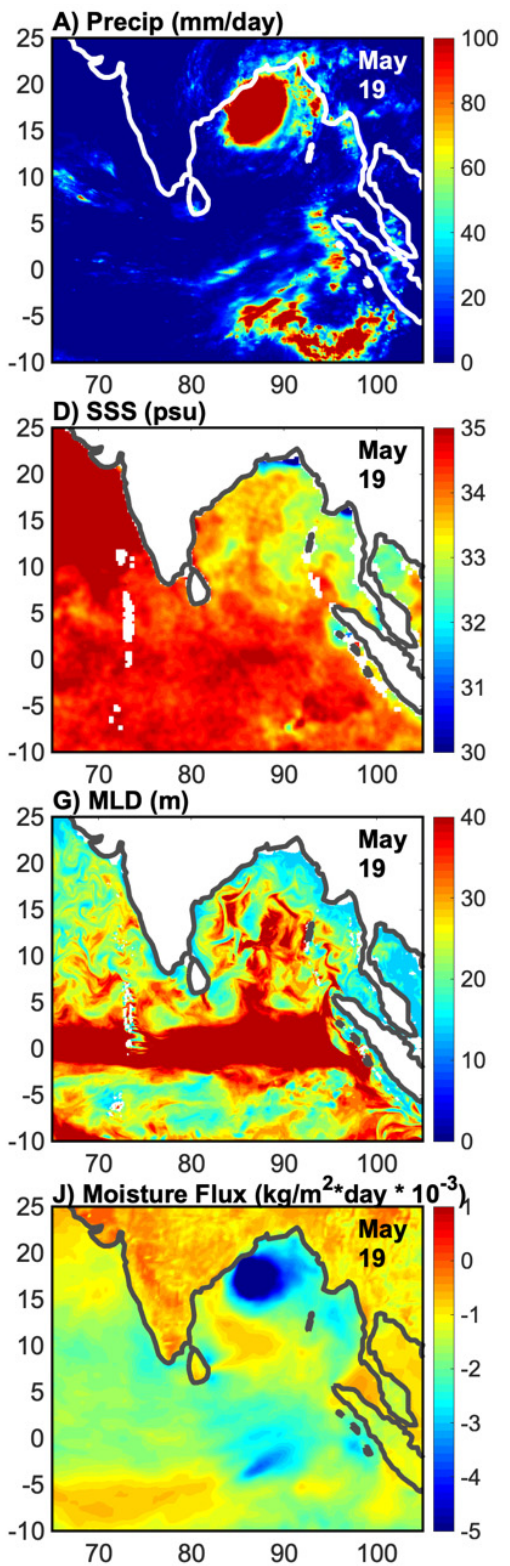

B) SLA (cm)
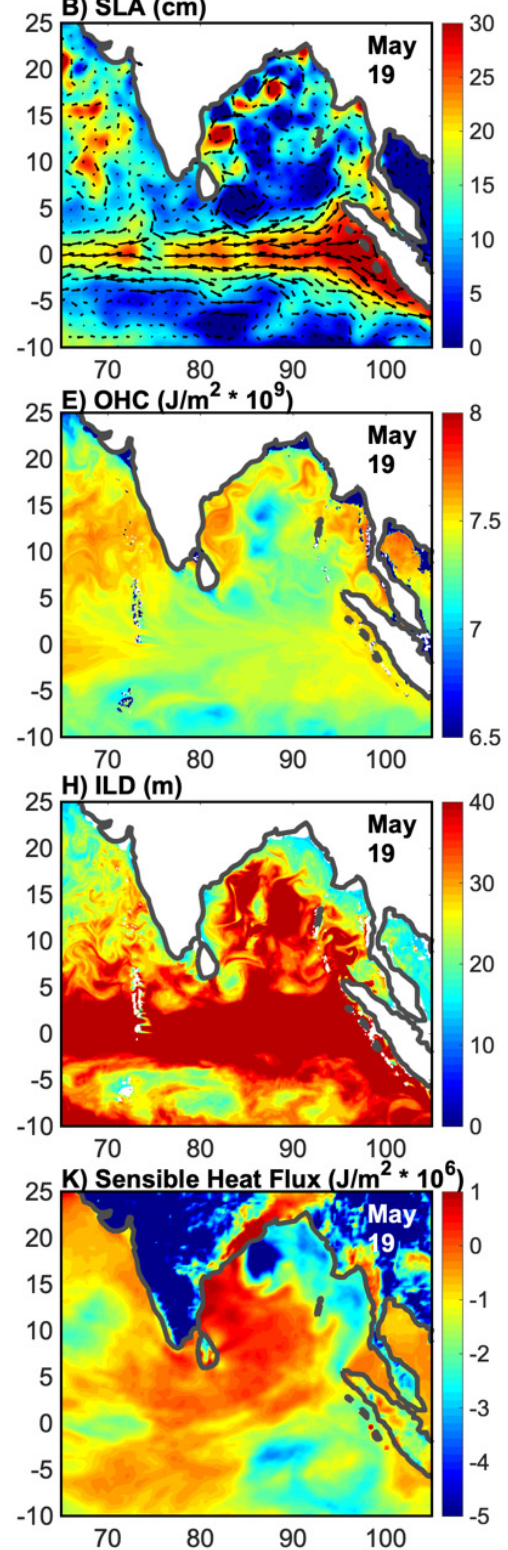
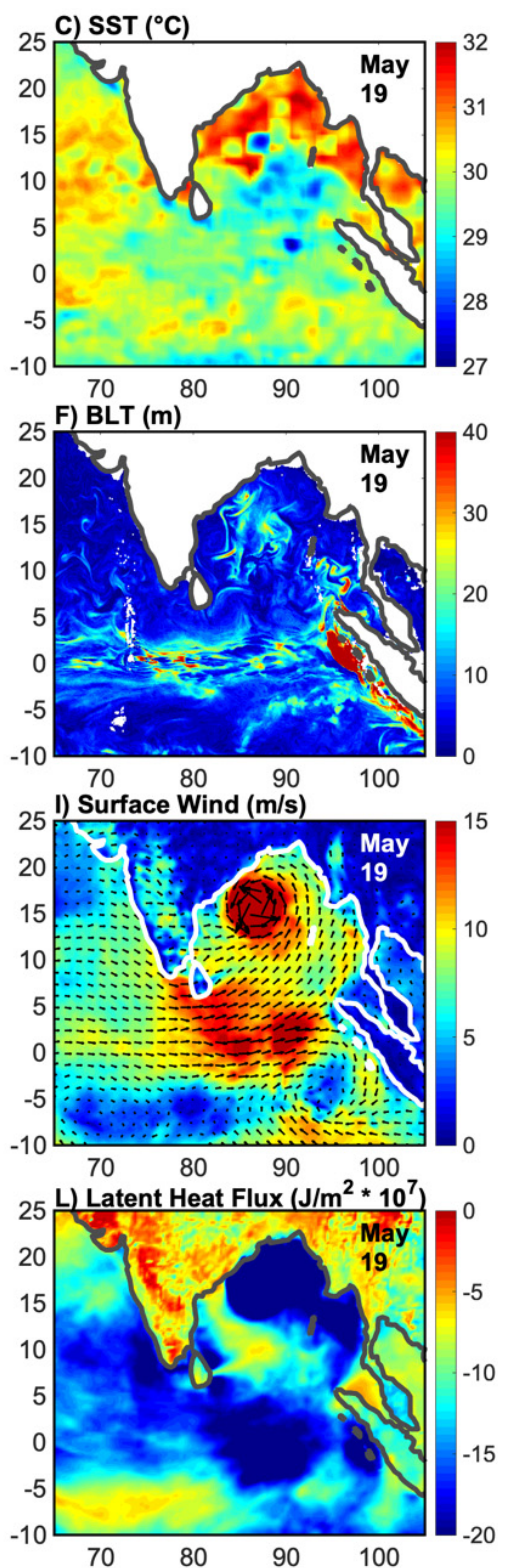

Figure 3. Multiparameter analysis of the Bay of Bengal on May 19, 2020 at the peak of the storm in (A) Global Precipitation Measurement (GPM) precipitation rate ( $\mathrm{mm} /$ day); (B) Copernicus Marine and Environment Monitoring Service (CMEMS) sea level anomalies (SLAs) (cm) overlaid with geostrophic currents (cm/s); (C) Nucleus for the European Modeling of the Ocean (NEMO) sea surface temperature (SST) data $\left({ }^{\circ} \mathrm{C}\right) ;($ D) NEMO sea surface salinity (SSS) data (psu); (E) 0-30 m ocean heat content (OHC; $\mathrm{J} / \mathrm{m}^{2 *} 10^{9}$ ) calculated from NEMO; (F) barrier layer thickness (BLT; $\mathrm{m}$ ) calculated from NEMO; (G) mixed layer depth (MLD; $\mathrm{m}$ ) calculated from NEMO; $(\mathbf{H})$ isothermal layer depth (ILD; $\mathrm{m}$ ) calculated from NEMO; (I) Cross-Calibrated Multi-Platform version 2 (CCMPv2) surface wind magnitude ( $\mathrm{m} / \mathrm{s}$; shaded) and vectors; (J) ERA5 instantaneous moisture flux $\left(\mathrm{kg} / \mathrm{m}^{2 *}\right.$ day $\left.{ }^{*} 10^{-3}\right)$; (K) ERA5 surface sensible heat flux $\left(\mathrm{J} / \mathrm{m}^{2} * 10^{6}\right)$; and $(\mathbf{L})$ ERA5 surface latent heat flux $\left(\mathrm{J} / \mathrm{m}^{2} * 10^{7}\right)$.

Three days after the passage of the storm in the Bay of Bengal, there was no notable precipitation or change in surface fluxes, although surface winds remained higher than prior to the cyclone and were predominantly southerly/southwesterly, more closely following southwest monsoon climatology and the conditions for monsoon onset (Figure 4A,I-L). The cold wake of the storm was apparent in SST, SSS, OHC, and ocean color data, with upwelling occurring along the storm track (Figures 1 and $4 \mathrm{C}-\mathrm{E})$. The upwelling signature was also apparent in mixed layer parameters, particularly MLD and 
ILD, where there was a shoaling of the mixed layer and isothermal layer directly to the west of the storm track and a deepening of both to the east of the storm (Figure 4F-H). SLAs did not appreciably change, though the progression of the downwelling coastal Kelvin wave along the edge of the eastern Bay was apparent (Figure 4C).
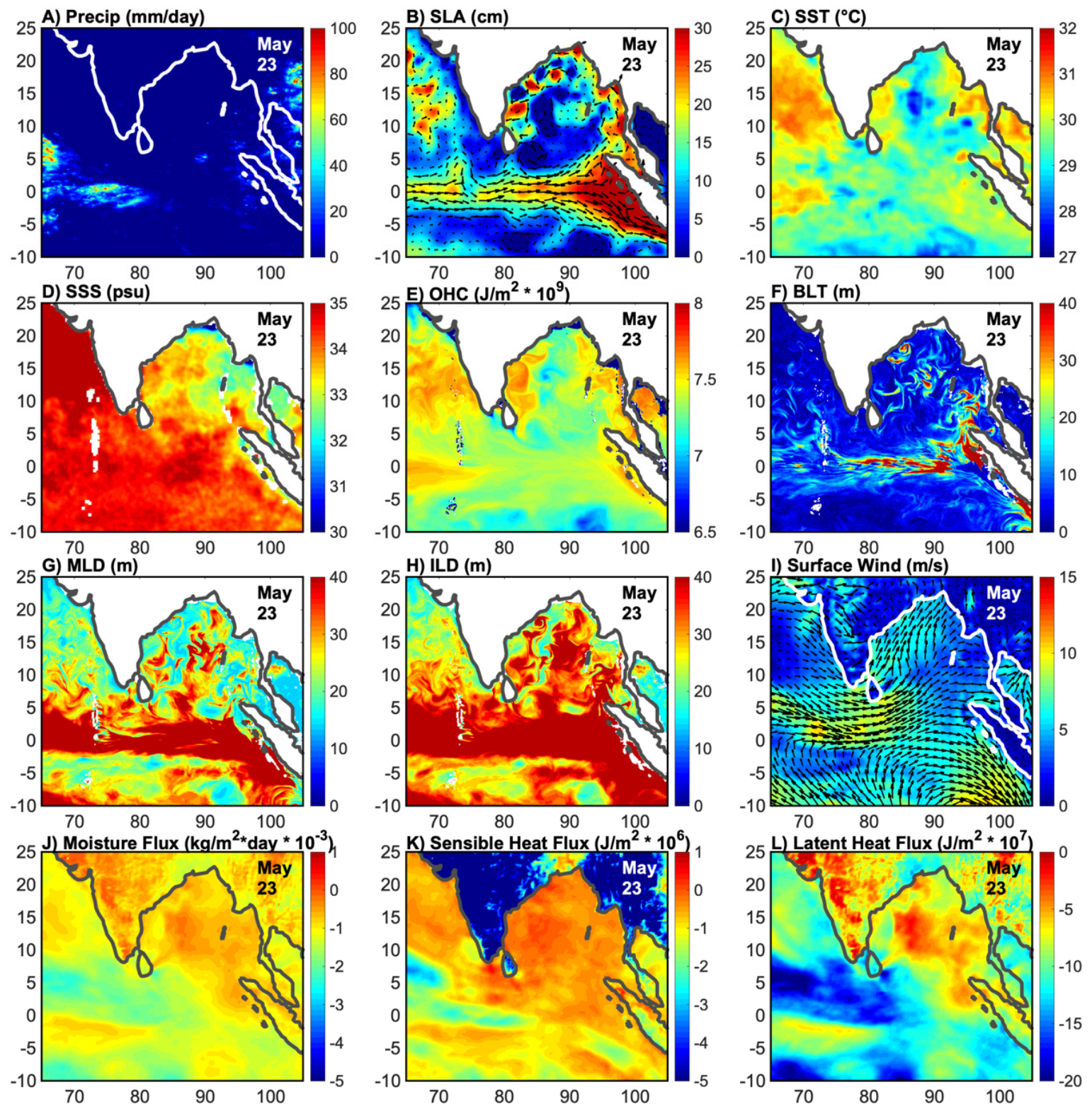

Figure 4. Multiparameter analysis of the Bay of Bengal on May 23, 2020 after the storm in (A) Global Precipitation Measurement (GPM) precipitation rate (mm/day); (B) Copernicus Marine and Environment Monitoring Service (CMEMS) sea level anomalies (SLAs) $(\mathrm{cm})$ overlaid with geostrophic currents $(\mathrm{cm} / \mathrm{s})$; (C) Nucleus for the European Modeling of the Ocean (NEMO) sea surface temperature (SST) data $\left({ }^{\circ} \mathrm{C}\right)$; (D) NEMO sea surface salinity (SSS) data (psu); (E) 0-30 m ocean heat content $\left(\mathrm{OHC} ; \mathrm{J} / \mathrm{m}^{2} * 10^{9}\right)$ calculated from NEMO; (F) barrier layer thickness (BLT; m) calculated from NEMO; $(\mathbf{G})$ mixed layer depth (MLD; m) calculated from NEMO; $(\mathbf{H})$ isothermal layer depth (ILD; m) calculated from NEMO; (I) Cross-Calibrated Multi-Platform version 2 (CCMPv2) surface wind magnitude ( $\mathrm{m} / \mathrm{s}$; shaded) and vectors; (J) ERA5 instantaneous moisture flux $\left(\mathrm{kg} / \mathrm{m}^{2 *} \mathrm{day}^{*} 10^{-3}\right)$; (K) ERA5 surface sensible heat flux $\left(\mathrm{J} / \mathrm{m}^{2} * 10^{6}\right)$; and $(\mathrm{L})$ ERA5 surface latent heat flux $\left(\mathrm{J} / \mathrm{m}^{2} * 10^{7}\right)$. 


\subsection{Impacts on the Bay of Bengal}

To investigate the impact of Amphan on the Bay of Bengal, a box-averaged cross-section of the Bay was taken along the storm track at $14^{\circ} \mathrm{N}$, where the minimum central pressure $(907 \mathrm{mb})$ was felt at the peak of storm intensity (Figure 5). Prior to the arrival of the storm, salinity was low in the upper $60 \mathrm{~m}$ of the water column, with values of $<32 \mathrm{psu}$ at $30 \mathrm{~m}$ depth. In the week prior to cyclogenesis, salinity values began to increase by as much as 1 psu throughout the water column, with higher salinity waters from below $60 \mathrm{~m}$ becoming entrained into depths at less than $40 \mathrm{~m}$. These values decreased between May 16 and 18 as the storm strengthened and approached $14^{\circ} \mathrm{N}$, where the cross-section was taken. Beginning on May 14, isotherms become vertical and MLD began to increase, suggesting the impacts of cyclogenesis on the region on the upper $20 \mathrm{~m}$ of the water column. This effect extended in both temperature and salinity down to $100 \mathrm{~m}$ (not shown), with the mixed layer deepening by $10 \mathrm{~m}$ with the passage of the storm. The resulting upwelling following the passage of Amphan on May 19 led to surface cooling in excess of $2.5^{\circ} \mathrm{C}$ and a 1 psu increase in salinity throughout the upper $60 \mathrm{~m}$ of the water column, the effects of which were still being felt nearly two weeks after the passage of the storm.

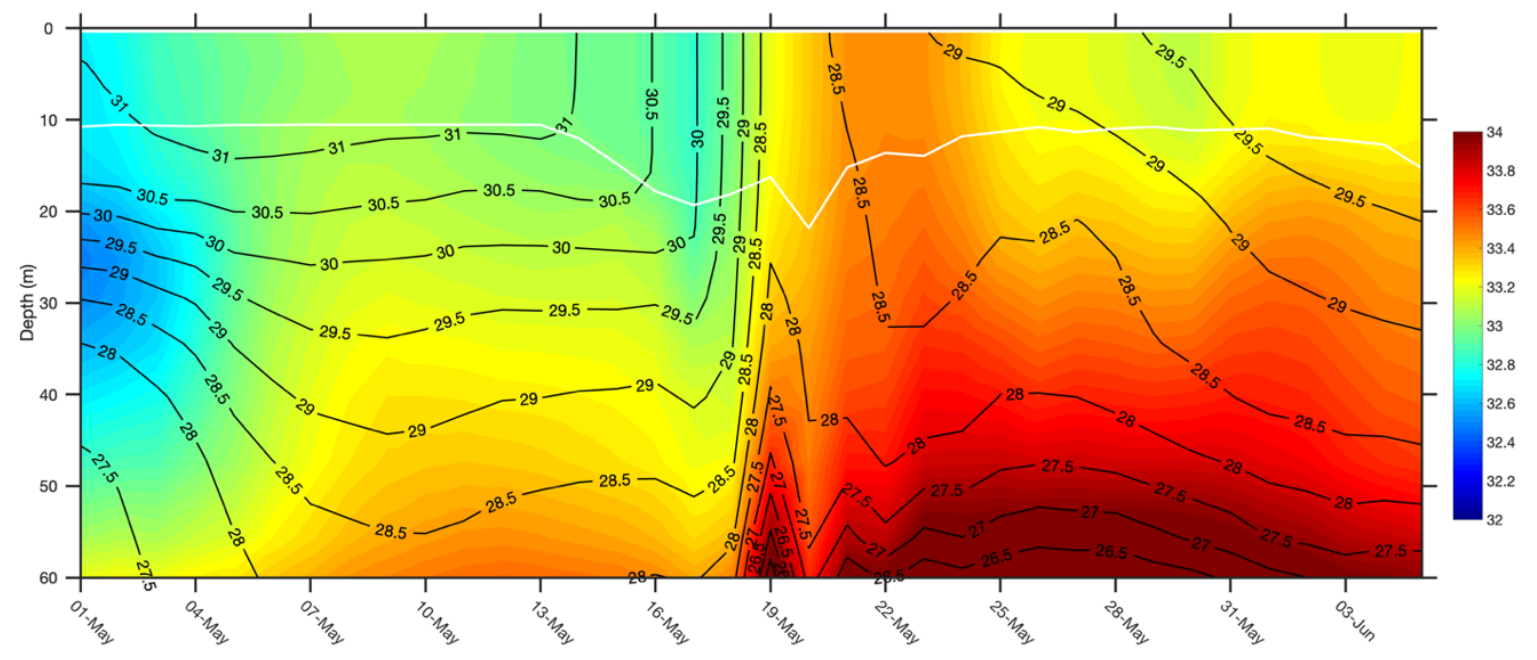

Figure 5. Box-averaged NEMO salinity (psu; shaded) overlaid with NEMO temperature contours $\left({ }^{\circ} \mathrm{C}\right.$ ) and calculated mixed layer depth ( $\mathrm{m}$; white line) in the Bay of Bengal $\left(86-88^{\circ} \mathrm{E}, 14^{\circ} \mathrm{N}\right)$ with depth from May 1 to June 5, 2020.

The effects of Amphan's passing were not uniformly felt along the storm track, with dramatic differences in the regional response in the Bay being apparent (Figure 6). Though the storm was generated in the southern Bay and progressed northward, the central Bay received comparatively less daily rainfall than either the southern or northern Bay (Figure 6A); however, the central Bay experienced the effects of Amphan in precipitation for two more days than the other regions. The northern Bay experienced the greatest amount of rainfall, with nearly $400 \mathrm{~mm}$ /day on May 19, even though the storm was beginning to weaken in intensity. Surface wind more closely followed the intensity of the storm (Figure 6B), where the central Bay experienced the highest wind speeds (closely followed by the northern Bay) and the southern Bay had the lowest averaged wind speeds. Surface geostrophic currents derived from altimetry did not appear to be substantially impacted by the passage of the storm (Figure 6C), although there was an overall increase in magnitude in both the southern and central Bay. SLAs, by contrast, decreased by up to $15 \mathrm{~cm}$ along the storm track (Figure 6D), likely as a result of the cooling SSTs (Figure 6E) and upwelling following the storm. This could also be seen in the spatial plots of SLAs and geostrophic currents (Figures 2b,3B and 4B). As seen in Figure 5, SSTs cooled dramatically following the passage of the storm, with a nearly $4{ }^{\circ} \mathrm{C}$ decrease in SST observed in the central Bay (Figure 6E). The response in SSS was less dramatic than that of SST (Figure 6F), although the central Bay still had a strong salinification leading up to the passage of the storm. 

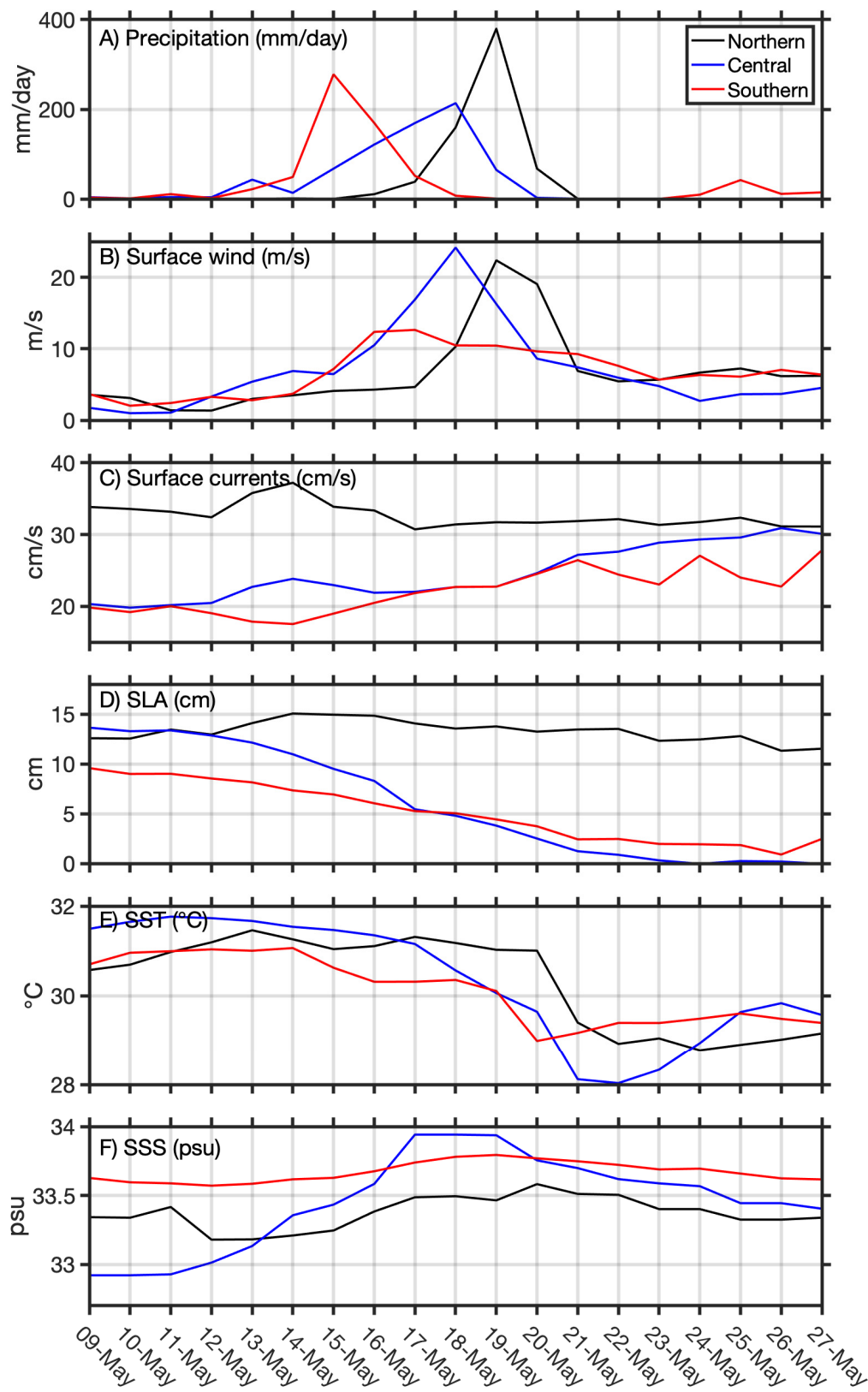

Figure 6. Box-averaged time series from May 9 to May 27, 2020 in the northern $\left(86-88^{\circ} \mathrm{E}, 15-20^{\circ} \mathrm{N}\right.$; black), central ( $86-88^{\circ} \mathrm{E}, 10-15^{\circ} \mathrm{N}$; blue), and southern $\left(86-88^{\circ} \mathrm{E}, 5-10^{\circ} \mathrm{N}\right.$; red) Bay of Bengal for (A) GPM precipitation (mm/day); (B) CCMPv2 surface wind magnitude (m/s); (C) CMEMS geostrophic surface currents (cm/s); (D) CMEMS SLA (cm); (E) OISST $\left({ }^{\circ} \mathrm{C}\right)$; and (F) SMAP SSS (psu).

While satellite observations largely followed patterns of cyclone intensity, with the central Bay experiencing the most pronounced response to the passage of Amphan, mixed layer parameters (Figure 7A-D) and surface fluxes (Figure 7E-G) more closely aligned with precipitation (Figure 6A). BLT was deepest in the central Bay following the maximum changes in salinity and temperature (Figure 7A); however MLD and ILD were both strongest in the southern Bay with a gradient of depths by latitude (Figure 7B,C). This followed the spatial patterns seen in Figures 2-4, where MLD and ILD both deepened most clearly in response to the downwelling Kelvin wave in the near-equatorial region. A 0-30 m OHC followed patterns of cyclone intensity, with the central Bay starting off with at least $1 \times 10^{8} \mathrm{~J} / \mathrm{m}^{2}$ more heat than the other regions. While small compared to overall OHC values, small changes in the OHC could still contribute to SSTs, latent heat fluxes, and available atmospheric moisture. The warm central Bay can most clearly be seen in Figure 2E, which shows that there were 
clearly much higher $\mathrm{OHC}$ values in the central Bay and along the storm track, likely contributing to the resulting cyclone intensity.
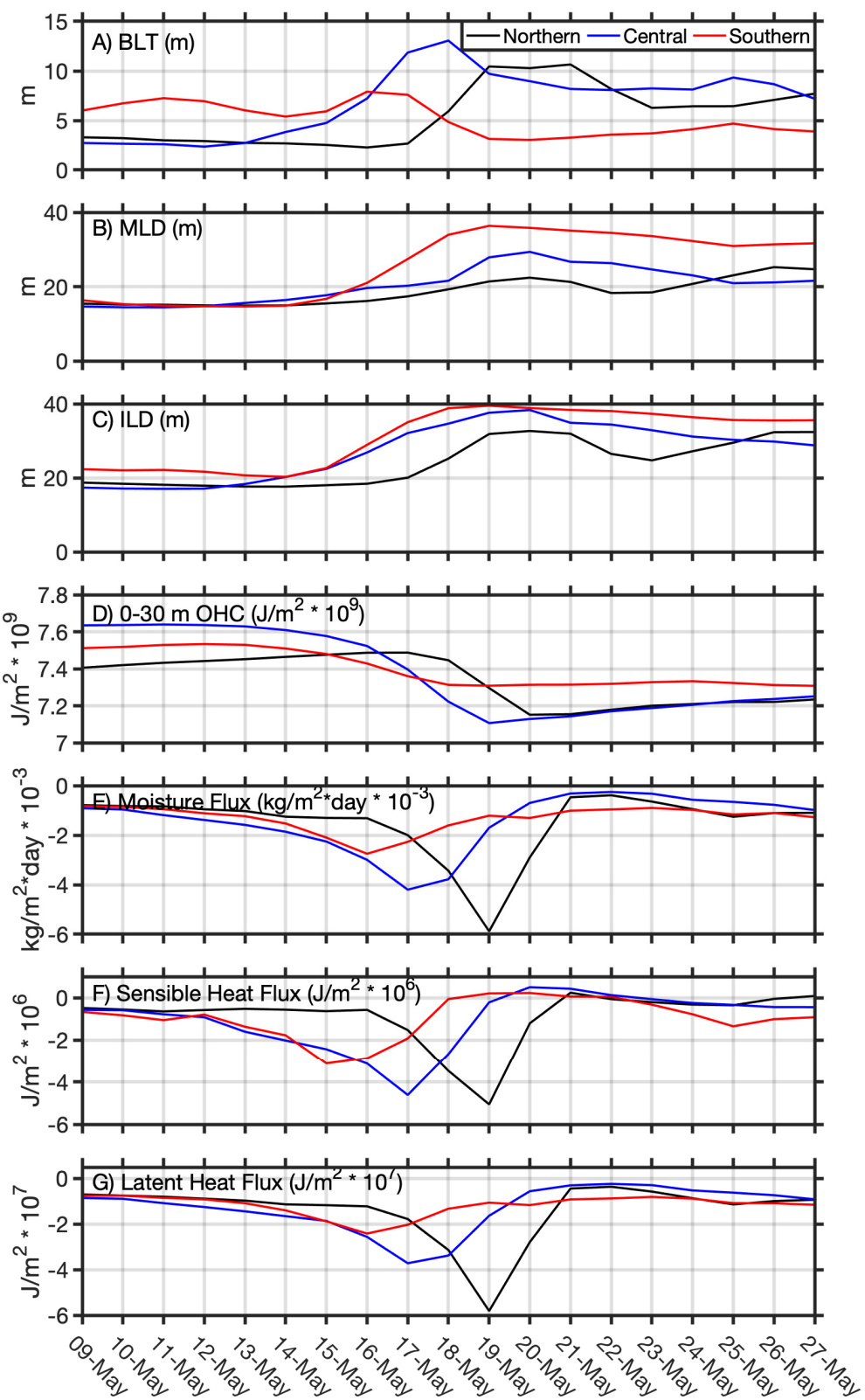

Figure 7. Box-averaged time series from May 9 to May 27, 2020 in the northern $\left(86-88^{\circ} \mathrm{E}\right.$, $15-20^{\circ} \mathrm{N}$; black), central $\left(86-88^{\circ} \mathrm{E}, 10-15^{\circ} \mathrm{N}\right.$; blue), and southern $\left(86-88^{\circ} \mathrm{E}, 5-10^{\circ} \mathrm{N}\right.$; red) Bay of Bengal for: (A) NEMO-derived BLT (m); (B) NEMO-derived MLD (m); (C) NEMO-derived ILD (m); (D) NEMO-derived 0-30 m OHC $\left(\mathrm{J} / \mathrm{m}^{2} * 10^{9}\right)$; (E) ERA5 instantaneous moisture flux $\left(\mathrm{kg} / \mathrm{m}^{2 *}\right.$ day $\left.^{*} 10^{-3}\right)$; (F) ERA5 surface sensible heat flux $\left(\mathrm{J} / \mathrm{m}^{2} * 10^{6}\right)$; and (G) ERA5 surface latent heat flux $\left(\mathrm{J} / \mathrm{m}^{2} * 10^{7}\right)$.

Surface fluxes more closely followed patterns of precipitation, with the highest magnitude fluxes in the northern Bay on May 19 and lower values seen in the central and southern Bay (Figure 7E-G). Latent heat fluxes are widely considered to be the primary fuel for cyclone intensity, and so while they were not the most important factor for observed minimum pressure and wind speed magnitude, these surface fluxes did help to increase the volume of precipitation associated with the storm in the northern Bay. 


\subsection{Equatorial Processes}

In order to better assess the propagation of the storm system, an unfiltered time-latitude plot for the storm track in the Bay of Bengal and equatorial region $\left(86-88^{\circ} \mathrm{E},-5-20^{\circ} \mathrm{N}\right)$ was created (Figure 8). The genesis, strengthening, and northward propagation of Amphan from May 14 to May 20 can be clearly seen in Figure 8a, with smaller systems dominating the southern Bay and equatorial region beginning in April that increased in both frequency and intensity in the weeks leading up to cyclogenesis. Satellite observations of SLAs, SST, and SSS all reflected the upwelling and cold wake along the storm track following the passage of the storm, with a particularly stark contrast in SST and SSS being apparent. While SSS rebounded to pre-cyclone values fairly quickly, both SLAs and SST did not return to pre-cyclone values even by the end of May and the beginning of the southwest monsoon season. Regarding SLAs, the arrival of the first downwelling Kelvin wave was most apparent around the equator, with the maximum in SLAs occurring concurrently with both cyclogenesis and peak storm intensity (Figure 8b).
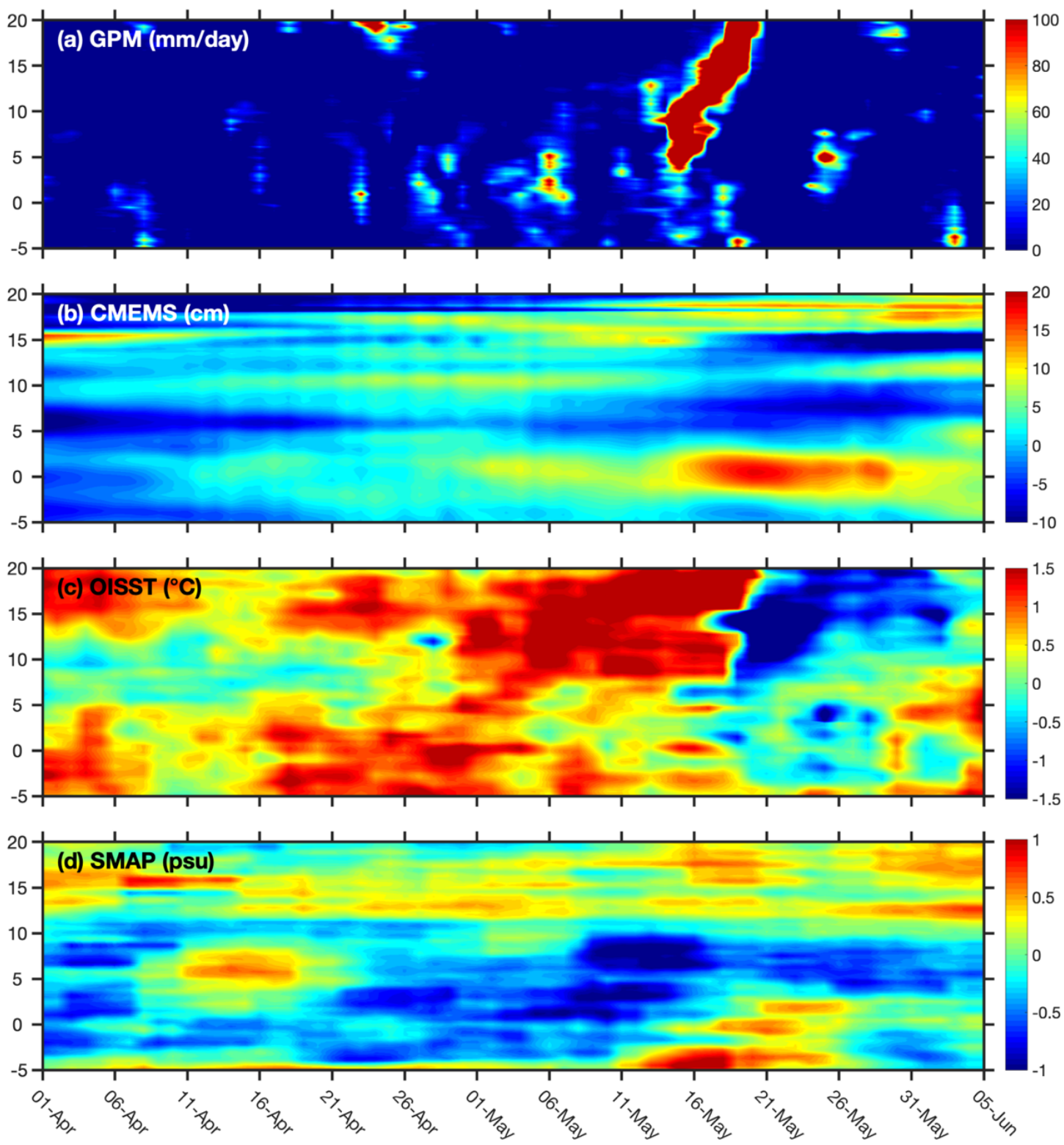

Figure 8. Time-latitude plots of (a) GPM precipitation rate (mm/day), (b) CMEMS SLA (cm), (c) OISST $\left({ }^{\circ} \mathrm{C}\right)$, and (d) SMAP SSS (psu) in the Bay of Bengal $\left(86-88^{\circ} \mathrm{E},-5-20^{\circ} \mathrm{N}\right)$ from April 1 to May 31, 2020 with the seasonal cycle removed. 
Given the relative dominance of equatorial processes in SLAs and the timing of the first downwelling Kelvin wave, the time-latitude fields in Figure 8 were next 30-90-day bandpass filtered with the seasonal cycle removed for the timescale of the $\mathrm{MJO}$, the passage of which has been noted by several previous studies [5,17-19] to trigger cyclogenesis in this region (Figure 9). The bandpass filtered fields indeed showed a pronounced 30-90-day mode in all four satellite parameters, with a strong 30-90-day signal occurring at the same time as cyclogenesis in the Bay. This was most pronounced in SLAs and SST (Figure 9b,c), with the maximum in SST occurring in the genesis region just prior to cyclogenesis.
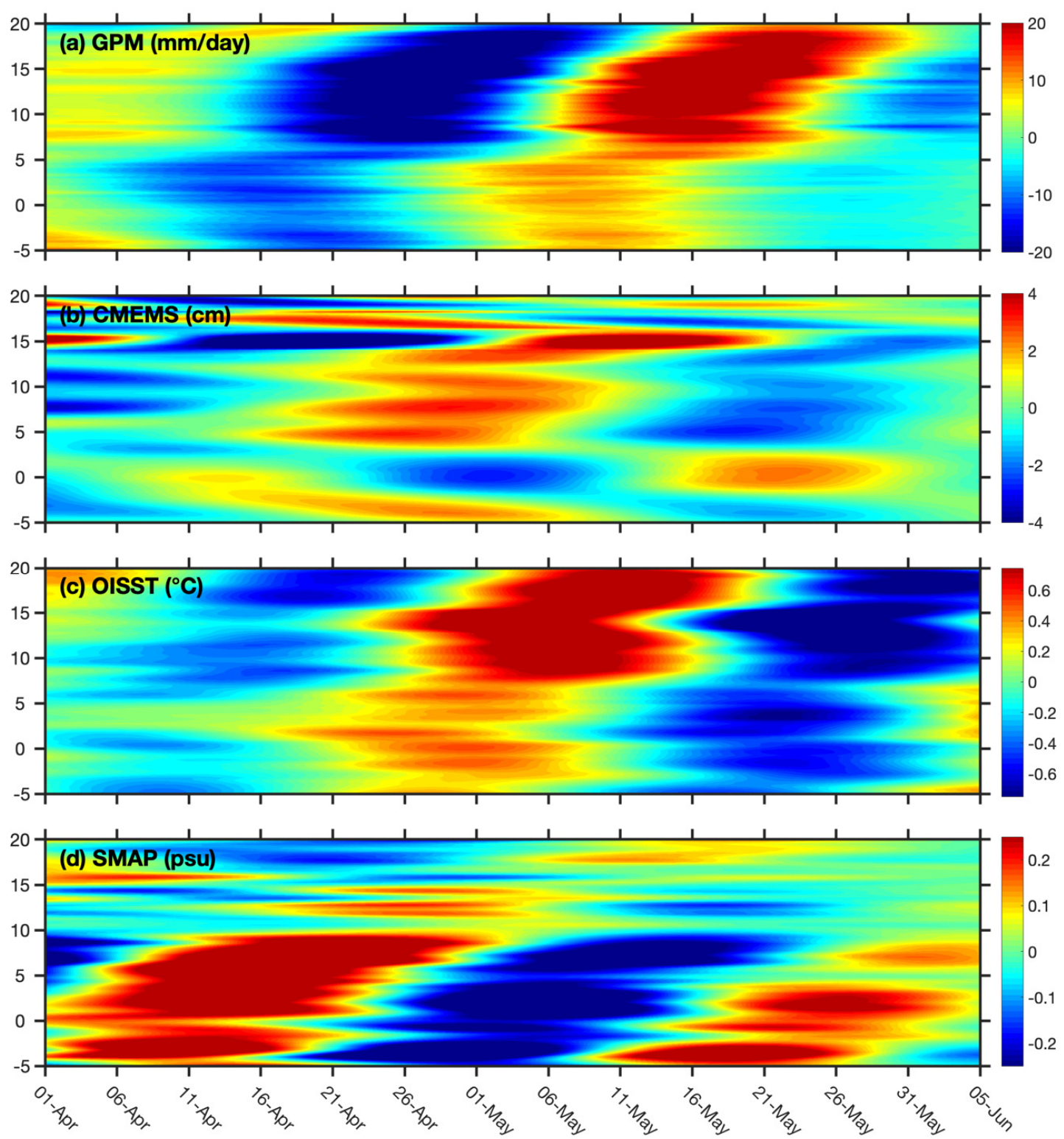

Figure 9. 30-90-day bandpass filtered time-latitude plots of (a) GPM precipitation rate (mm/day), (b) CMEMS SLA (cm), (c) OISST $\left({ }^{\circ} \mathrm{C}\right)$, and (d) SMAP SSS (psu) in the Bay of Bengal $\left(86-88^{\circ} \mathrm{E},-5-20^{\circ} \mathrm{N}\right)$ from April 1 to May 31, 2020 with the seasonal cycle removed.

\subsection{Impact on Southwest Monsoon Onset}

Given the timing of Amphan and the passage of the MJO through the equatorial Indian Ocean in late May, we next turned our attention to the southeastern Arabian Sea where the southwest monsoon began on June 1, 2020, in accordance with climatology. The anomalously strong positive IOD in 2019 modified coastal Kelvin wave propagation in the Bay and reduced the strength of the EICC flow into 
the southeastern Arabian Sea. Previous studies [26,49,50] have shown that freshwater fluxes into this region are critical for monsoon onset and that onset following a positive IOD is typically delayed due to the associated dynamics. Despite these apparent setbacks, the 2020 southwest monsoon onset with climatology on June 1 . An unfiltered time-latitude plot of this region $\left(65-60^{\circ} \mathrm{E},-5-20^{\circ} \mathrm{N}\right)$ revealed a northward propagation of precipitation beginning after May 1 (Figure 10a). While the propagation was not as apparent in SLAs, a northward propagation of high SSTs in excess of $31{ }^{\circ} \mathrm{C}$, which are associated with the Arabian Sea Mini Warm Pool [25,26,30], began in April and preceded precipitation by two weeks (Figure 10c). No clear propagation was apparent in SSS.
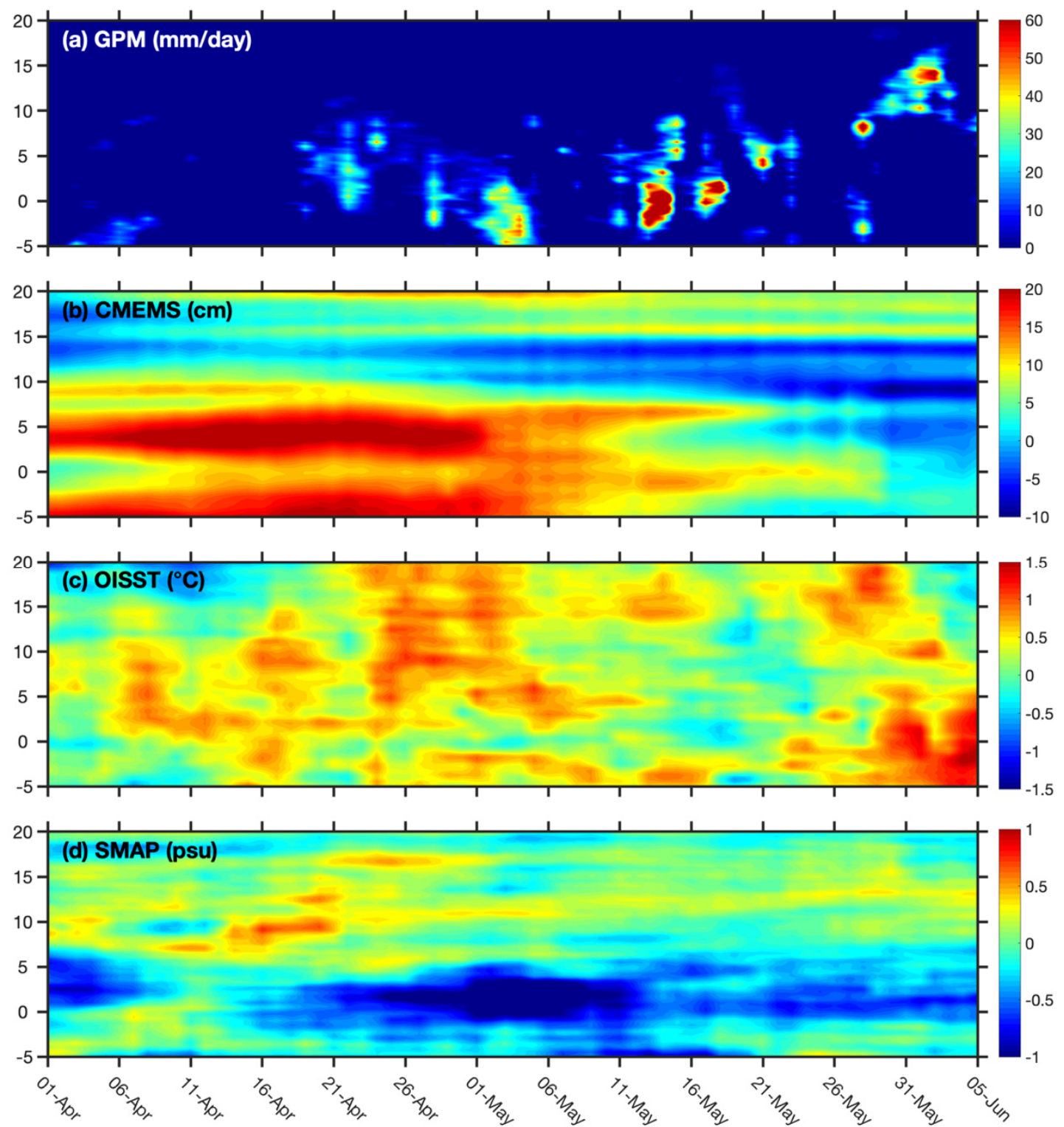

Figure 10. Time-latitude plots of (a) GPM precipitation rate (mm/day), (b) CMEMS SLA (cm), (c) OISST $\left({ }^{\circ} \mathrm{C}\right)$, and (d) SMAP SSS (psu) in the southeastern Arabian Sea $\left(65-70^{\circ} \mathrm{E},-5-20^{\circ} \mathrm{N}\right)$ from April 1 to May 31, 2020 with the seasonal cycle removed.

To identify the impact of potential MJO propagation on southwest monsoon onset, the time-latitude fields in Figure 10 were bandpass-filtered for the 30-90-day range (Figure 11) as in Figure 9. The northward propagation of the MJO system (BSISO) in precipitation is apparent in Figure 11a, with precipitation increasing on May 1 and extending northward through monsoon onset. The equatorial 
propagation of the oceanic MJO is apparent in all three parameters, with the timing of warming SSTs (Figure 11c) and the planetary wave propagation (Figure 11b) preceding precipitation.
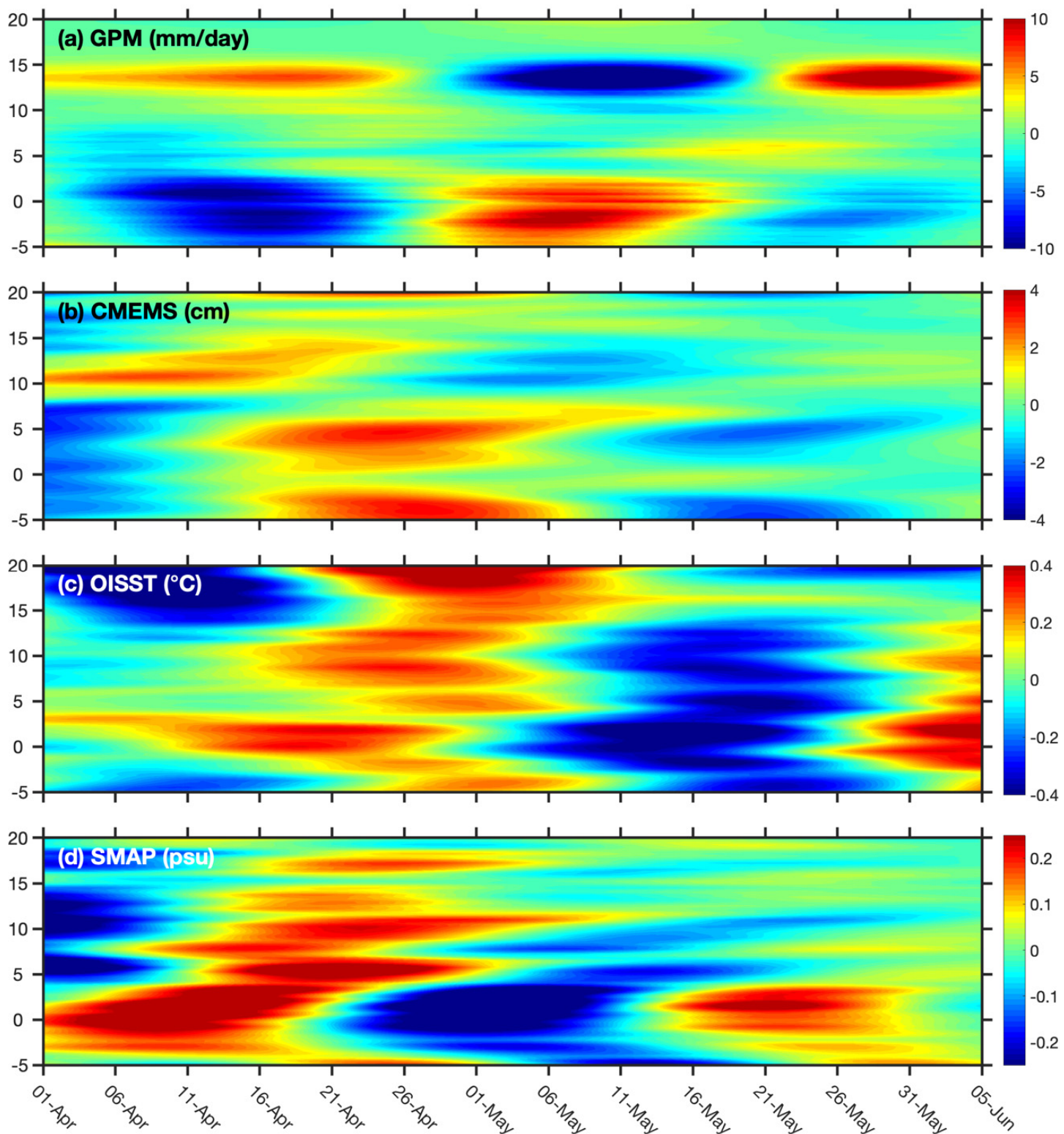

Figure 11. 30-90-day filtered time-latitude plots of (a) GPM precipitation rate (mm/day), (b) CMEMS SLA $(\mathrm{cm}),(\mathbf{c}) \operatorname{OISST}\left({ }^{\circ} \mathrm{C}\right)$, and $(\mathbf{d})$ SMAP SSS $(\mathrm{psu})$ in the southeastern Arabian Sea $\left(65-70^{\circ} \mathrm{E},-5-20^{\circ} \mathrm{N}\right)$ from April 1 to May 31, 2020 with the seasonal cycle removed.

The passage of the MJO through the equatorial Indian Ocean was accompanied by the triggering of a northward-propagating BSISO event (Figures 11 and 12). As this BSISO event moved northward through the Arabian Sea, the MJO continued to propagate eastward, with the further northward propagation of planetary wave activity triggering cyclogenesis in the Bay of Bengal and ultimately leading to the formation of Cyclone Amphan. The passage of the BSISO and the effects of Amphan were strongly felt in the southeastern Arabian Sea in moisture flux, with a minimum on May 17-18 that reached nearly $-0.12 \mathrm{~kg} / \mathrm{m}^{2} \mathrm{~s}$. Moisture flux values associated with these systems in mid-May exceeded the monsoon onset response on June 1-2, which was atypical of the usual gradual build of moisture observed in other years. Though the passage of tropical systems through this region is not uncommon prior to monsoon onset, the unique combination of BSISO passage, tropical cyclone formation, and timing helped to precondition the southeastern Arabian Sea to a state that likely 
contributed to the timing, location, and strength of the onset given the available atmospheric moisture at the time.
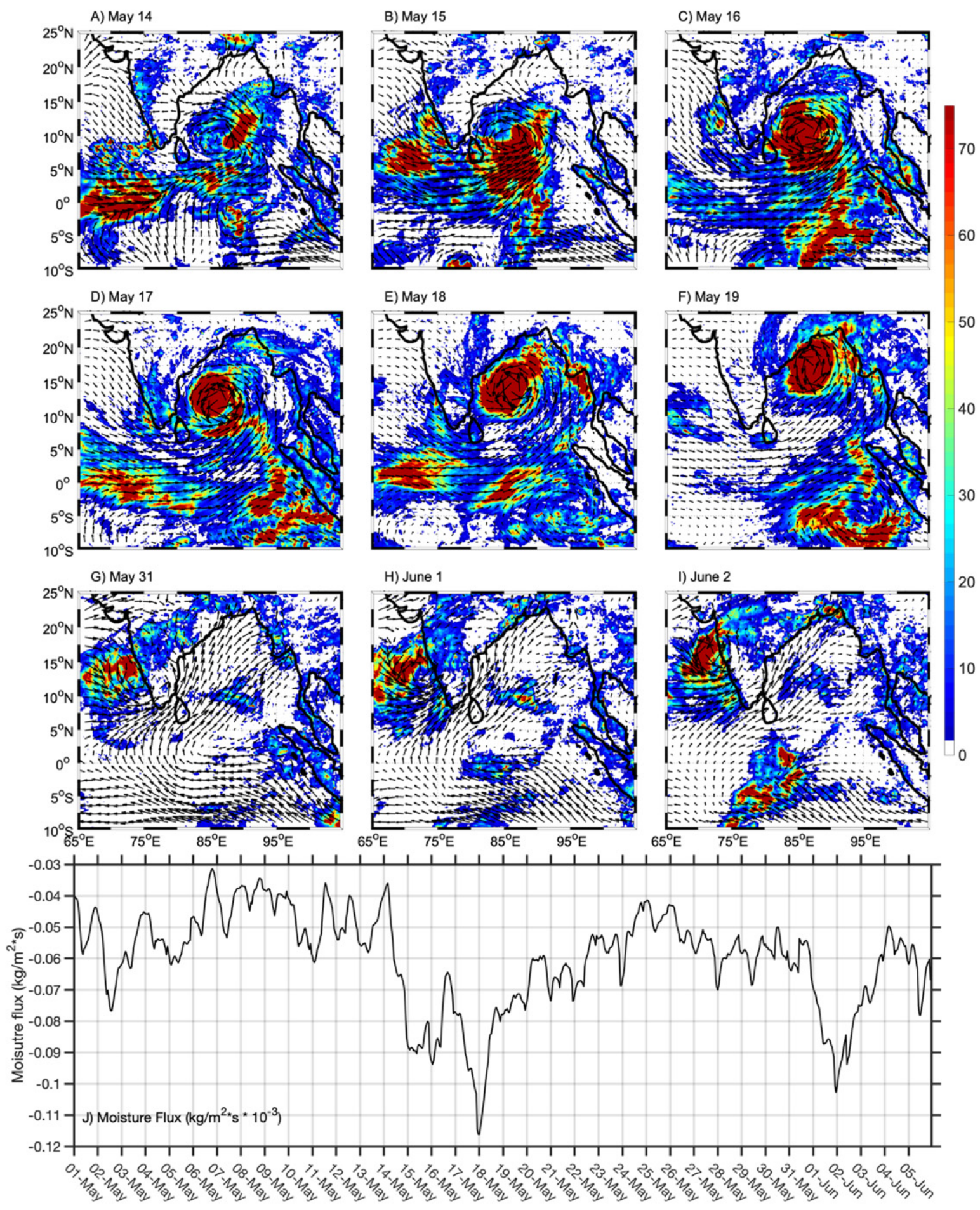

Figure 12. Spatial plots of GPM precipitation rate (shaded; mm/day) for: (A) May 14, (B) May 15, (C) May 16, (D) May 17, (E) May 18, (F) May 19, (G) May 31, (H) June 1, and (I) June 2, with $(\mathbf{J})$ a box-averaged time series of ERA5 instantaneous moisture flux data $\left(\mathrm{kg} / \mathrm{m}^{2 *} \mathrm{~s}^{*} 10^{-3}\right)$ in the southeastern Arabian Sea $\left(65-70^{\circ} \mathrm{E}, 6-13^{\circ} \mathrm{N}\right)$ from May 1 to June 5, 2020. 


\section{Discussion}

\subsection{Cyclogenesis}

The multiparameter analysis of Cyclone Amphan revealed that the genesis of storm occurred concurrently with the passage of an oceanic downwelling Kelvin wave (Figures 2-4) and the MJO (Figures 8 and 9). Previous studies of tropical cyclone activity have analyzed the impact of tropical waves on cyclogenesis $[4,5,14,17,18,51]$, both globally and in the northern Indian Ocean. While there have been several studies that have analyzed the impact of atmospheric Kelvin waves on cyclogenesis $[5,14,17,19]$, finding them to have the greatest impact on cyclogenesis in Northern Hemisphere in spring [5], fewer have focused on the impact oceanic planetary waves have on cyclogenesis [4]. A 2010 case study of Cyclone Nargis (2008) in the Bay of Bengal [4] found that the passage of a downwelling off-equatorial Rossby Wave in the Bay ultimately caused a shoaling of the mixed layer and raised SSTs, helping to alter the cyclone track. While Rossby waves were not apparently involved in directing the track of Cyclone Amphan, our analysis suggested that the arrival of an equatorial downwelling Kelvin wave and the successive propagation of a downwelling coastal Kelvin wave helped to depress the thermocline and increase local SSTs, 0-30 m OHC, MLD, ILD, and BLT (Figures 2-4). While this occurred closer to the equator, a multiparameter analysis of the conditions before and during the storm suggested that the passage of the oceanic Kelvin wave did help to precondition the genesis region for cyclone development (Figures 3 and 4 ).

Despite the timing of this Kelvin wave and its significant impact on the upper ocean, another equatorial wave-like phenomenon was more dominantly involved in Amphan's development: the MJO. Previous studies have repeatedly shown that the MJO is a key contributor to global cyclogenesis $[5,17,19]$. One such study found that the spring peak in northern Indian Ocean cyclogenesis occurred concurrently with statistical peaks in MJO, equatorial Rossby wave, and Kelvin wave activity [5]. This study found that waves enhanced low level vorticity and that the storms that formed along the convectively active portion of the wave helped to enhance deep convection in the genesis region that ultimately led to genesis. This was consistent with our findings, where the passage of the positive (convective) phase of the MJO initiated several smaller storms in the near-equatorial Bay that later developed and organized into Amphan (Figures 2, 9 and 12).

While equatorial waves undoubtedly played a significant role in cyclogenesis, it was also the northward-propagating BSISO, related to the MJO, and its associated convection that likely helped to trigger cyclogenesis (Figure 12). Previous studies of cyclogenesis in the Bay have found that the most favorable conditions for cyclogenesis occur in May and October-November, due to a weak vertical shear, as well as that the passage of the BSISO also produces high absolute vorticity and relative humidity [18]. This was likely the case with Cyclone Amphan, which was generated in May following the passage of the MJO and BSISO.

\subsection{Southwest Monsoon Onset}

The 2020 southwest monsoon onset occurred on June 1, 2020 over the southwestern state of Kerala. The timing of Amphan and the MJO were both such that the moisture flux and precipitation associated with both systems helped to precondition the southeastern Arabian Sea for monsoon onset and helped to ensure that onset occurred on time. Studies of the conditions necessary for southwest monsoon onset have found that there is a convergence of heat and moisture in the eastern Bay of Bengal [20], such as that observed concurrently with Cyclone Amphan (Figures 2-4 and 12). Onset is then characterized by a convergence of heat, moisture, and diabatic heating over the Arabian Sea, with increased low-level kinetic energy and net tropospheric moisture over the same region [20]. The moisture flux and increasing SSTs in the southeastern Arabian Sea impacted by both Amphan and the MJO helped to create these necessary conditions in the Arabian Sea for monsoon onset to occur (Figures 10-12). 
The MJO and the northward-propagating BSISO have been shown by previous studies, and they are well-known to impact monsoon onset and variability [20-24,51,52]. It has been found that the phase of the MJO and the location of its convective center can heavily impact the timing and strength of monsoon onset [21], and a normal onset occurs when the MJO is in the western Indian Ocean. Beyond the contributions of moisture and convection to the southeastern Arabian Sea, the MJO and BSISO help to establish low-level westerlies in this region and also impact nonlinear eddy momentum transport, which helps to create the conditions necessary for onset to occur [23,24]. It would seem that this was the case in 2020, where the passage of the MJO, BSISO, and Amphan transported moisture into the southeastern Arabian Sea and established surface northwesterly winds over the southeastern Arabian Sea. Thus, is appears that this perfect storm of tropical systems all worked together to allow for 2020 to have a climatological onset despite occurring after a strong positive IOD year [6].

With the changing climate and the relative importance of ISOs and synoptic systems in determining monsoon onset, it is now, more than ever, crucial that we improve our monitoring and forecasting of these systems through improved observations and modeling. Because the MJO and BSISO, as well as tropical cyclones and monsoon onset, are all highly coupled systems, it is increasingly clear that the accurate forecasting and modeling of these events will rely on high quality remotely sensed observations and the assimilation of these data into modeled forecasts.

\section{Conclusions}

The MJO is the dominant form of intraseasonal variability in the tropics that impacts tropical cyclogenesis and informs monsoon strength and onset. This has thus far been in the case leading into the 2020 monsoon season, as the MJO and BSISO have been seen to impact the cyclogenesis of Cyclone Amphan (2020), which developed into an intense tropical system, and southwest monsoon onset.

Cyclone Amphan (2020) developed into an exceptionally intense storm, reaching a minimum central pressure of $907 \mathrm{mb}$ on May 19 and unleashing almost $400 \mathrm{~mm}$ /day of precipitation in the northern Bay of Bengal. This storm was allowed to rapidly intensify due to an exceptionally high 0-30 m $\mathrm{OHC}$ and the arrival of a downwelling equatorial Kelvin wave, which depressed the thermocline, increased SSTs, deepened the mixed layer, and helped to precondition the southern Bay of Bengal for cyclogenesis. Cyclogenesis occurred around $8^{\circ} \mathrm{N}$ following the passage of the convective phase of the $\mathrm{MJO}$, which released a northward-propagating BSISO that helped to provide the moisture and pre-existing convection necessary for cyclogenesis.

In addition to impacting Amphan's cyclogenesis, the passage of the MJO also impacted southwest monsoon onset. The northward-propagating BSISO and equatorial MJO both helped to set up the low-level westerlies in the southeastern Arabian Sea, as well as to transport moisture into the onset region. Further moisture was then transported in conjunction with Amphan, which actually produced a greater moisture flux in the southeastern Arabian Sea than the onset itself. The timing and intensity of these events all worked together to allow for monsoon onset to occur on June 1 despite the exceptionally low freshwater flux into the southeastern Arabian Sea due to the strong positive IOD in 2019.

This complex interplay of mixed layer processes, ISOs, tropical cyclones, planetary waves, and monsoon onset highlights our continuing need for high resolution, high quality, near real-time observations from satellites to better inform model forecasts. ISO forecasting and cyclone intensity forecasting both remain difficult, and improved observations and the assimilation of these observations will help to improve these forecasts. The southwest monsoon and tropical cyclones in the Bay of Bengal directly impact well over a billion people, and it is thus critical that, moving forward, we improve our monitoring, understanding, and forecasting of these complex phenomena.

Author Contributions: H.L.R.-S. and B.S. conceived and designed the data analysis and interpretation of the results. H.L.R.-S. prepared all the figures and writing of this article, and B.S. designed the project, guided this work, and corrected the paper. All authors have read and agreed to the published version of the manuscript. 
Funding: This research was funded by the United States Office of Naval Research's project, Oceanic Control of Monsoon Intra-Seasonal Oscillations in the Tropical Indian Ocean and the Bay of Bengal (MISO-BOB), Awarded \#N00014-17-2468, awarded to B.S.

Acknowledgments: The authors would like to thank the editors and anonymous reviewers whose comments significantly improved the quality of this manuscript. NASA/JAXA GPM precipitation data were taken from NASA's Earthdata database with a 4-h latency (https://pmm.nasa.gov/data-access/d ownloads/gpm). CMEMS daily near real-time blended SLA and geostrophic currents were obtained from: (https://resources.marine.copernicus.eu/?option=com_csw\&view=details\&product_id=SEALEVEL_GL O_PHY_L4_NRT_OBSERVATIONS_008_046). CCMPv2.0 near real-time surface winds were obtained from RSS at http://www.remss.com/measurements/ccmp/. OISST were taken in near real-time from NOAA/OAR/ESRL PSL (https://psl.noaa.gov/data/gridded/data.noaa.oisst.v2.highres.html). SMAPv4.3 data were taken from NASA/JPL PO.DAAC Drive (https://podaac-tools.jpl.nasa.gov/drive/files/SalinityDensity/smap/L3/JPL/V4.3/8day_running/2 020). NOAA gap-filled ocean color data were obtained from (https://coastwatch.noaa.gov/cw/satellite-data-prod ucts/ocean-color/near-real-time/viirs-multi-sensor-gap-filled-chlorophyll-dineof.html). NOAA best track data for Amphan (2020) were taken from (https://www.ssd.noaa.gov/PS/TROP/DATA/ATCF/JTWC/bio012020.dat). NEMOv3.1 ocean model data were taken from CMEMS at: (https://resources.marine.copernicus.eu/?option=com _csw\&view=details\&product_id=GLOBAL_ANALYSIS_FORECAST_PHY_001_024). ERA5 reanalysis on single levels were obtained from C3S at: (https://cds.climate.copernicus.eu/cdsapp\#!/dataset/reanalysis-era5-single-leve ls?tab=overview).

Conflicts of Interest: The authors declare no conflict of interest.

\section{References}

1. Smitha, A.; Rao, K.H.; Sengupta, D. Effect of May 2003 tropical cyclone on physical and biological processes in the Bay of Bengal. Int. J. Remote Sens. 2006, 27, 5301-5314. [CrossRef]

2. Singh, O.P.; Masood, T.; Khan, A.; Rahman, M.S. Has the frequency of intense tropical cyclones increased in the north Indian Ocean? Curr. Sci. 2001, 80, 575-580.

3. Singh, O.P. Long-term trends in the frequency of severe cyclones of Bay of Bengal: Observations and simulations. Mausam 2007, 58, 59-66.

4. Yu, L.; McPhaden, M.J. Ocean preconditioning of Cyclone Nargis in the Bay of Bengal: Interaction between Rossby waves, Surface Fresh Waters, and Sea Surface Temperatures. J. Phys. Oceanogr. 2011, 41, 1741-1755. [CrossRef]

5. Frank, W.M.; Roundy, P.E. The role of tropical waves in tropical cyclogenesis. Mon. Weather Rev. 2006, 134, 2397-2417. [CrossRef]

6. Climate Monitoring Graphs: IOD Index Time Series. Available online: http://www.bom.gov.au/climate/enso/ indices.shtml?bookmark=iod (accessed on 2 August 2020).

7. ENSO Outlook. Available online: http://www.bom.gov.au/climate/enso/outlook/ (accessed on 2 August 2020).

8. Mahala, B.K.; Nayak, B.K.; Mohanty, P.K. Impacts of ENSO and IOD on tropical cyclone activity in the Bay of Bengal. Nat. Hazards 2015, 75, 1105-1125. [CrossRef]

9. Zhang, C. Madden-Julian Oscillation. Rev. Geophys. 2005, 43. [CrossRef]

10. Wheeler, M.C.; Hendon, H.H. An All-Season Real-Time Multivariate MJO Index: Development of an Index for Monitoring and Prediction. Mon. Weather. Rev. 2004, 132, 1917-1932. [CrossRef]

11. Straub, K.H. MJO initiation in the real-time multivariate MJO index. J. Clim. 2013, 26, 1130-1151. [CrossRef]

12. Shoup, C.G.; Subrahmanyam, B.; Roman-Stork, H.L. Madden-Julian Oscillation-Induced Sea Surface Salinity Variability as Detected in Satellite-Derived Salinity. Geophys. Res. Lett. 2019, 46, 9748-9756. [CrossRef]

13. Roman-Stork, H.L.; Subrahmanyam, B.; Trott, C.B. Monitoring Intraseasonal Oscillations in the Indian Ocean Using Satellite Observations. J. Geophys. Res. Ocean. 2020, 125, 1-22. [CrossRef]

14. Straub, K.H.; Kiladis, G.N. Interactions between the boreal summer intraseasonal oscillation and higher-frequency tropical wave activity. Mon. Weather Rev. 2003, 131, 945-960. [CrossRef]

15. Krishnamurti, T.N.; Jana, S.; Krishnamurti, R.; Kumar, V.; Deepa, R.; Papa, F.; Bourassa, M.A.; Ali, M.M. Monsoonal intraseasonal oscillations in the ocean heat content over the surface layers of the Bay of Bengal. J. Mar. Syst. 2017, 167, 19-32. [CrossRef]

16. Vecchi, G.A.; Harrison, D.E. Monsoon breaks and subseasonal sea surface temperature variability in the Bay of Bengal. J. Clim. 2002, 15, 1485-1493. [CrossRef]

17. Schreck, C.J.; Molinari, J. Tropical cyclogenesis associated with Kelvin waves and the Madden-Julian oscillation. Mon. Weather Rev. 2011, 139, 2723-2734. [CrossRef] 
18. Yanase, W.; Satoh, M.; Taniguchi, H.; Fujinami, H. Seasonal and intraseasonal modulation of tropical cyclogenesis environment over the bay of bengal during the extended summer monsoon. J. Clim. 2012, 25, 2914-2930. [CrossRef]

19. Schreck, C.J. Kelvin waves and tropical cyclogenesis: A global survey. Mon. Weather Rev. 2015, 143, $3996-4011$. [CrossRef]

20. Raju, P.V.S.; Mohanty, U.C.; Bhatla, R. Onset Characteristics of the Southwest Monsoon over India. Int. J. Climatol. 2005, 182, 167-182. [CrossRef]

21. Bhatla, R.; Singh, M.; Pattanaik, D.R. Impact of Madden-Julian oscillation on onset of summer monsoon over India. Theor. Appl. Climatol. 2017, 128, 381-391. [CrossRef]

22. Wang, B.; Webster, P.; Kikuchi, K.; Yasunari, T.; Qi, Y. Boreal summer quasi-monthly oscillation in the global tropics. Clim. Dyn. 2006, 27, 661-675. [CrossRef]

23. Qi, Y.; Zhang, R.; Li, T.; Wen, M. Impacts of intraseasonal oscillation on the onset and interannual variation of the Indian summer monsoon. Chinese Sci. Bull. 2009, 54, 880-884. [CrossRef]

24. Taraphdar, S.; Zhang, F.; Leung, L.R.; Chen, X.; Pauluis, O.M. MJO Affects the Monsoon Onset Timing Over the Indian Region. Geophys. Res. Lett. 2018, 45, 10011-10018. [CrossRef]

25. Nyadjro, E.S.; Subrahmanyam, B.; Murty, V.S.N.; Shriver, J.F. The role of salinity on the dynamics of the Arabian Sea mini warm pool. J. Geophys. Res. Ocean. 2012, 117, 1-12. [CrossRef]

26. Roman-Stork, H.L.; Subrahmanyam, B.; Murty, V.S.N. The Role of Salinity in the Southeastern Arabian Sea in Determining Monsoon Onset and Strength. J. Geophys. Res. Ocean. 2020, 125. [CrossRef]

27. Deepa, R.; Oh, J.H. Indian summer monsoon onset vortex formation during recent decades. Theor. Appl. Climatol. 2014, 118, 237-249. [CrossRef]

28. Rao, R.R.; Jitendra, V.; GirishKumar, M.S.; Ravichandran, M.; Ramakrishna, S.S.V.S. Interannual variability of the Arabian Sea Warm Pool: Observations and governing mechanisms. Clim. Dyn. 2015, 44, 2119-2136. [CrossRef]

29. Shenoi, S.S.C.; Shankar, D.; Shetye, S.R. On the sea surface temperature high in the Lakshadweep Sea before the onset of the southwest monsoon. J. Geophys. Res. Ocean. 1999, 104, 15703-15712. [CrossRef]

30. Vinayachandran, P.N.; Shankar, D.; Kurian, J.; Durand, F.; Shenoi, S.S.C. Arabian Sea mini warm pool and the monsoon onset vortex. Curr. Sci. 2007, 93, 203-214.

31. Rao, R.R.; Girish Kumar, M.S.; Ravichandran, M.; Rao, A.R.; Gopalakrishna, V.V.; Thadathil, P. Interannual variability of Kelvin wave propagation in the wave guides of the equatorial Indian Ocean, the coastal Bay of Bengal and the southeastern Arabian Sea during 1993-2006. Deep. Res. Part I Oceanogr. Res. Pap. 2010, 57, 1-13. [CrossRef]

32. Huffman, G.J.; Bolvin, D.T.; Braithwaite, D.; Hsu, K.-L.; Joyce, R.J.; Kidd, C.; Nelkin, E.J.; Sorooshian, S.; Stocker, E.F.; Tan, J.; et al. Integrated Multi-satellite Retrievals for the Global Precipitation Measurement (GPM) Mission (IMERG). In Satellite Precipitation Measurement; Springer: Cham, Switzerland, 2020; pp. 343-353. [CrossRef]

33. Atlas, R.; Hoffman, R.N.; Ardizzone, J.; Leidner, S.M.; Jusem, J.C.; Smith, D.K.; Gombos, D. A cross-calibrated, multiplatform ocean surface wind velocity product for meteorological and oceanographic applications. Bull. Am. Meteorol. Soc. 2011, 92, 157-174. [CrossRef]

34. Le Traon, P.Y.; Nadal, F.; Ducet, N. An improved mapping method of multisatellite altimeter data. J. Atmos. Ocean. Technol. 1998, 15, 522-534. [CrossRef]

35. Ducet, N.; Le Traon, P.Y.; Reverdin, G. Global high-resolution mapping of ocean circulation from TOPEX/Poseidon and ERS-1 and -2. J. Geophys. Res. Ocean. 2000, 105, 19477-19498. [CrossRef]

36. Entekhabi, D.; Njoku, E.G.; O’Neill, P.E.; Kellogg, K.H.; Crow, W.T.; Edelstein, W.N.; Entin, J.K.; Goodman, S.D.; Jackson, T.J.; Johnson, J.; et al. The soil moisture active passive (SMAP) mission. Proc. IEEE 2010, 98, 704-716. [CrossRef]

37. Reynolds, R.W.; Smith, T.M.; Liu, C.; Chelton, D.B.; Casey, K.S.; Schlax, M.G. Daily high-resolution-blended analyses for sea surface temperature. J. Clim. 2007, 20, 5473-5496. [CrossRef]

38. Liu, X.; Wang, M. Filling the gaps of missing data in the merged VIIRS SNPP/NOAA-20 ocean color product using the DINEOF method. Remote Sens. 2019, 11, 178. [CrossRef]

39. Ampahn Best Track Data. Available online: https://www.ssd.noaa.gov/PS/TROP/DATA/ATCF/JTWC/bio012 020.dat (accessed on 2 August 2020).

40. Madec, G. NEMO Ocean Engine; Version 3.3; Inst. Pierre-Simon Laplace (IPSL): Paris, France, 2011; pp. 1-332. 
41. Momin, I.M.; Mitra, A.K.; Mahapatra, D.K.; Rajagopal, E.N.; Harenduprakash, L. Indian Ocean simulation results from NEMO global ocean model. Indian J. Mar. Sci. 2013, 42, 425-430.

42. Roman-Stork, H.L.; Subrahmanyam, B.; Murty, V.S.N. Quasi-biweekly oscillations in the Bay of Bengal in observations and model simulations. Deep. Res. Part II Top. Stud. Oceanogr. 2019, 104609. [CrossRef]

43. Hersbach, H.; Bell, B.; Berrisford, P.; Hirahara, S.; Horányi, A.; Muñoz-Sabater, J.; Nicolas, J.; Peubey, C.; Radu, R.; Schepers, D.; et al. The ERA5 global reanalysis. Q. J. R. Meteorol. Soc. 2020, 146, 1999-2049. [CrossRef]

44. Uppala, S.M.; Kållberg, P.W.; Simmons, A.J.; Andrae, U.; da Costa Bechtold, V.; Fiorino, M.; Gibson, J.K.; Haseler, J.; Hernandez, A.; Kelly, G.A.; et al. The ERA-40 re-analysis. Q. J. R. Meteorol. Soc. 2005, 131, 2961-3012. [CrossRef]

45. Horii, T.; Masumoto, Y.; Ueki, I.; Hase, H.; Mizuno, K. Mixed layer temperature balance in the eastern Indian Ocean during the 2006 Indian Ocean dipole. J. Geophys. Res. Ocean. 2009, 114, 1-14. [CrossRef]

46. de Boyer Montégut, C.; Madec, G.; Fischer, A.S.; Lazar, A.; Iudicone, D. Mixed layer depth over the global ocean: An examination of profile data and a profile-based climatology. J. Geophys. Res. Ocean. 2004, 109, 1-20. [CrossRef]

47. Subrahmanyam, B.; Roman-Stork, H.L.; Murty, V.S.N. Response of the Bay of Bengal to 3-7-day synoptic oscillations during the southwest monsoon of 2019. J. Geophys. Res. Ocean. 2020, 125, e2020JC016200. [CrossRef]

48. Trott, C.B.; Subrahmanyam, B.; Roman-Stork, H.L.; Murty, V.S.N.; Gnanaseelan, C. Variability of Intraseasonal Oscillations and Synoptic Signals in Sea Surface Salinity in the Bay of Bengal. J. Clim. 2019, 32, 6703-6728. [CrossRef]

49. Sankar, S.; Kumar, M.R.R.; Reason, C. On the relative roles of El Nino and Indian Ocean Dipole events on the Monsoon Onset over Kerala. Theor. Appl. Climatol. 2011, 103, 359-374. [CrossRef]

50. Nienhaus, M.J.; Subrahmanyam, B.; Murty, V.S.N. Altimetric Observations and Model Simulations of Coastal Kelvin Waves in the Bay of Bengal. Mar. Geod. 2012, 35, 190-216. [CrossRef]

51. Masunaga, H. Seasonality and regionality of the Madden-Julian Oscillation, Kelvin wave, and equatorial Rossby wave. J. Atmos. Sci. 2007, 64, 4400-4416. [CrossRef]

52. Lawrence, D.M.; Webster, P.J. The boreal summer intraseasonal oscillation: Relationship between northward and eastward movement of convection. J. Atmos. Sci. 2002, 59, 1593-1606. [CrossRef] 